\title{
Trying to choose the less bad route: Individual migratory behaviour of Atlantic salmon smolts (Salmo salar L.) approaching a bifurcation between a hydropower station and a navigation canal
}

\author{
Séverine Renardy ${ }^{\mathrm{a},{ }^{*}, \text { Abderrahmane Takriet }}{ }^{\mathrm{b}}$, Jean-Philippe Benitez ${ }^{\mathrm{a}}$, Arnaud Dierckx ${ }^{\mathrm{a}}$, \\ Raf Baeyens ${ }^{\mathrm{c}}$, Johan Coeck ${ }^{\mathrm{c}}$, Ine S. Pauwels ${ }^{\mathrm{c}}$, Ans Mouton ${ }^{\mathrm{c}}$, Pierre Archambeau ${ }^{\mathrm{b}}$, \\ Benjamin Dewals $^{\mathrm{b}}$, Michel Pirotton ${ }^{\mathrm{b}}$, Sébastien Erpicum ${ }^{\mathrm{b}}$, Michaël Ovidio ${ }^{\mathrm{a}}$ \\ ${ }^{a}$ UR-FOCUS, Management of Aquatic Resources and Aquaculture Unit, Laboratory of Fish Demography and Hydroecology, University of Liège, Liège, Belgium \\ ${ }^{\mathrm{b}}$ UR-UEE, Laboratory of Hydraulics in environmental and civil engineering (HECE), University of Liege, Liège, Belgium \\ ${ }^{\mathrm{c}}$ INBO, Research Institute for Nature and Forest, Team Aquatic Management, Brussel, Belgium
}

\section{A R T I C L E I N F O}

\section{Keywords:}

Migratory fish

Downstream migration

Hydroelectricity

Hydraulics

River restoration

Large-sized river

\begin{abstract}
A B S T R A C T
Contrary to small- and medium-sized rivers, little attention has been paid to the downstream migration of Atlantic salmon smolts in large-sized rivers and the size-related impact of hydropower stations. From 2014 to 2016, we investigated the downstream migration of $n=72$ acoustic-tagged smolts in the Meuse river at a bifurcation zone between a hydropower station equipped with three Kaplan turbines and a navigation canal. A hydrodynamic model that solves the depth-integrated shallow water equations on a Cartesian grid using a finite volume technique was used to infer the influence of water discharge and flow velocity on the smolts' behaviour upstream of the hydroelectric complex. Of the migrating smolts, $41.5 \%$ performed back and forth movements before approaching the complex for the first time, sometimes over long distances and at a slow pace, leading to significant delays (3-298 h). Beyond about $250 \mathrm{~m}^{3} \mathrm{~s}^{-1}$, the water flow direction changes towards the hydropower station with a gradual acceleration. A median water discharge of $161 \mathrm{~m}^{3} \mathrm{~s}^{-1}$ and associated median flow velocity of $0.14 \mathrm{~m} \mathrm{~s}^{-1}$ tended to favour a more direct and downstream movement towards the hydropower station. On the other hand, the navigation canal was mainly approached at low water discharge (median $132 \mathrm{~m}^{3}$ $\mathrm{s}^{-1}$ ), due to a higher flow velocity (median $0.11 \mathrm{~m} \mathrm{~s}^{-1}$ ) at the entrance. Of the released smolts, only $38.6 \%$ passed through the complex, of which $36.4 \%$ migrated by the navigation canal and $63.6 \%$ by the hydropower station, with a median research time of 04:44. Among all the released individuals, the escapement rate at the end of the study site was $2.9 \%$ by the canal and $8.3 \%$ by the Meuse river. This site, which offers two non-optimal, unattractive and unsafe migration routes, turns out to be problematic for successful downstream smolt migration.
\end{abstract}

\section{Introduction}

For several decades, rivers have been fragmented and homogenised to enable man-made activities, such as boat navigation, hydropower production, and water regulation (Parrish et al., 1998; Baras and Lucas, 2001; Nilsson et al., 2005), which have caused a drastic reduction and the extinction of several migratory fish species (Larinier and Travade, 2002; Katopodis and Williams, 2012). The Atlantic salmon (Salmo salar Linnaeus, 1758) is one of the most sensitive species due to the complexity of its life cycle, its important ecological requirements in freshwater and marine environments, the challenge of performing precise homing, and the extent of the downstream and upstream migrations at the smolt and adult stages (Parrish et al., 1998; Thorstad et al., 2012). Most populations are declining, and some strains have completely disappeared from European and American rivers during the last decades. Reintroduction efforts have been performed in some countries (e.g., France, Belgium, Germany, The Netherlands) with some success, but some major problems persist before the establishment of self-sustainable populations. In highly fragmented environments, the success of migrations is dependent on the performance of the up- and downstream fish-passage structures and mitigation and management measures to facilitate smolt and adult movements (Katopodis and

\footnotetext{
* Corresponding author.

E-mail address: severine.renardy@uliege.be (S. Renardy).
} 
Williams, 2012; Williams et al., 2012; Fjeldstad et al., 2018). Significant progress has been made in fishway design to restore the upstream migration of different fish species, including Atlantic salmon adults, with some that have demonstrated good performance (Benitez et al., 2018; Silva et al., 2018; Ovidio et al., 2020). On the other hand, the re-establishment of a successful and quick downstream migration often remains difficult and challenging in anthropised rivers (Holbrook et al., 2011; Fjeldstad et al., 2012; Newton et al., 2019; Ovidio et al., 2021). The escapement rate of smolts to the sea is often insufficient to expect further quantitative returns of adults (Thorstad et al., 2008).

In small- and medium-sized rivers, one of the most often encountered problems is the accumulation of physical migration barriers such as hydropower stations throughout the fish migration routes (Noatch and Suski, 2012; Katopodis and Williams, 2012; Haraldstad et al., 2018, 2019). Such structures cause considerable delays in migration and significant mortality notably due to energy expenditure (Marschall et al., 2011; Nyqvist et al., 2017; Ovidio et al., 2017), to predation close to the sites (Coutant and Whitney, 2000; Koed et al., 2002; Brevé et al., 2014) and turbine passage (Coutant and Whitney, 2000; Serrano et al., 2009; Fu et al., 2016; Pauwels et al., 2020). During their downstream migration, Atlantic salmon smolts, which face classical physical barriers to migration, will express different behavioural tactics to find a migration route to pass the site (Haraldstad et al., 2019; Renardy et al., 2020). Depending on the typology of the site, the final choice of a migration route may be influenced by a single or a combination of environmental or biological factors. Some authors have already mentioned the effect of water discharge (Fjeldstad et al., 2012; Cheng and Gallinat, 2004; Persson et al., 2019; Renardy et al., 2020), water temperature (CastroSantos and Perry, 2012), the smolts' morphological and physiological state (Coutant and Whitney, 2000; Fjeldstad et al., 2012; Tetard et al., 2019), and the progression in time of the migration season (Tetard et al., 2019).

In large rivers, migrating fish may also encounter other additional types of man-made structures, such as diversions, navigation canals and navigation locks. Some authors have underlined their potential effects in terms of delays of downstream migration, mortality, and reduction of the seaward escapement rate for different fish species (Steel et al., 2013, Johnston et al., 2018, Oncorhynchus tshawytscha L.; Hondorp et al., 2017, Acipenser fulvescens L.; Vergeynst et al., 2019, Anguilla anguilla L. \& Salmo salar L.). Despite their absence of physical effects, navigation canals and diversions may be in some situations favourable and in others unfavourable (Lin et al., 2020). Navigation canals can be a more direct migration route to the sea (Verhelst et al., 2018a), but they are regularly associated with low flow velocities, pumping stations, artificial water discharge, and flow direction changes. These artificial regulations may cause a discontinuous flow, which may induce fish disorientation (Verhelst et al., 2018a). In some particular places, smolts have to choose between a hydropower station and a navigation canal as two potential migration routes. This represents a challenging situation with a choice between two potentially inadequate routes to continue downstream migration. Knowledge of environmental factors that influence their choice, as well as the success in continuing downstream depending on the selected route is of great importance, but has not been investigated before.

The use of hydraulic modelling in combination with acoustic telemetry helps to understand the choice made by migrating fish, the passage success and their further behaviour afterwards (Vergeynst, 2018; Szabo-Meszaros et al., 2019; Silva et al., 2020). Combining detailed hydraulic modelling and precise behavioural analyses enabled a better visualization of the influence of hydrodynamic characteristics on smolts' behaviour upstream of migration barriers (Vergeynst, 2018; Silva et al., 2020) or the identification, by simulations, of the most suitable mitigation measures to favour a quick and safe migration (Szabo-Meszaros et al., 2019).

In the Belgian Meuse river, during their seaward migration, the migrating smolts will encounter a migration barrier offering two migration routes, a navigation canal and a hydropower station equipped with three Kaplan turbines, and without fish protection devices. This represents a complex situation to manage for the smolts during their route to the sea. By using acoustic-tagged Atlantic salmon smolts and numerical modelling of the hydrodynamic characteristics of the site, we investigated the downstream migration behaviour of smolts confronted with this site, to determine (1) the variability of smolts' individual research behaviour at the site, (2) the quantification of the migration routes used by the smolts, (3) the influence of the distribution of the flow velocity and its fluctuation on their orientation and route choices, and (4) the downstream migratory patterns of smolts after the selection of a migration route.

\section{Materials and methods}

\subsection{Study area}

The Meuse river is a $950 \mathrm{~km}$ long international river (Fig. 1A - source in France, flows across Belgium and has its estuary in The Netherlands) with a catchment area of $36,000 \mathrm{~km}^{2}$. In the Belgian course, the Meuse river corresponds to a bream fish zone (Huet, 1949) and hosts 36 different species, of which $75 \%$ are cyprinids, such as the common bream (Abramis brama Linnaeus, 1758), the roach (Rutilus rutilus Linnaeus, 1758), and the chub (Squalius cephalus Linnaeus, 1758) (Benitez et al., 2018). The lower part of the Belgian Meuse river is highly anthropised, modified by navigation canals, with rectified and artificial banks, fragmented by dams and ship locks, water regulation, and hydropower production. The average annual temperature and discharge during the study, as measured in Liège, was $15.2{ }^{\circ} \mathrm{C}$ and $163.75 \mathrm{~m}^{3} \mathrm{~s}^{-1}$. The Ourthe river, a main tributary of the Meuse river, is a medium-sized river that is $235 \mathrm{~km}$ long and has a mean annual water temperature of $10.6{ }^{\circ} \mathrm{C}$. The river is classified as a barbel zone (Huet, 1949) with the presence of 29 fish species also dominated by cyprinids.

The study site corresponds to the Meuse river stretch from the confluence with the Ourthe river to the Flemish and Dutch border (Fig. 1B) and includes two hydropower stations: the Monsin and the Lixhe hydropower stations (Fig. 1B; W1 \& W2). The main study site is located in Liège, from the confluence with the Ourthe river to the Monsin dam and hydropower station on the one hand, and the entrance of the Albert navigation canal on the other hand (Fig. 1C). This stretch is approximately $4.5 \mathrm{~km}$ long and, on this stretch, the Meuse river is divided in two, with the so-called diversion flowing on the right of the main riverbed (Fig. 1C).

The Monsin dam regulates the water level along the entire study site, i.e., at the Albert Canal entrance and in the downstream part of the Ourthe river. An average annual water discharge of $36.5 \mathrm{~m}^{3} \mathrm{~s}^{-1}$ is directed towards the Albert Canal, which modifies the natural watercourse of the Meuse river. Due to navigation locks in the Albert Canal, water discharge can sometimes be inverted. The other part is directed towards the hydropower station situated in the natural course of the Meuse river. The partition of water varies considerably depending on the upstream flow. The hydropower station next to the dam has a $225 \mathrm{~m}$ long intake channel that diverts water towards three Kaplan turbines with $3 \times 150 \mathrm{~m}^{3} \mathrm{~s}^{-1}$ nominal flows, a rotational speed of $65.2 \mathrm{rpm}$, a diameter of $13.83 \mathrm{~m}$, and a head of $5.6 \mathrm{~m}$. The dam is $180 \mathrm{~m}$ long and is equipped with six spillway gates, which were constantly closed during the surveys depicted in this study. A vertical slot fishway, with a water discharge of $0.8 \mathrm{~m}^{3} \mathrm{~s}^{-1}$, is located between the power station and the dam, and its performance was already assessed for upstream migrating fish (Benitez et al., 2018).

Currently, the Monsin hydropower station combined with the entrance of the Albert Canal is a zone where migrating smolt can choose two different migration routes towards the sea (Fig. 1D). In the direction of the main course of the Meuse river, the hydropower station of Lixhe is located $13 \mathrm{~km}$ downstream of the Monsin hydropower station and represents the border between Belgium and The Netherlands (Fig. 1B; W2). 


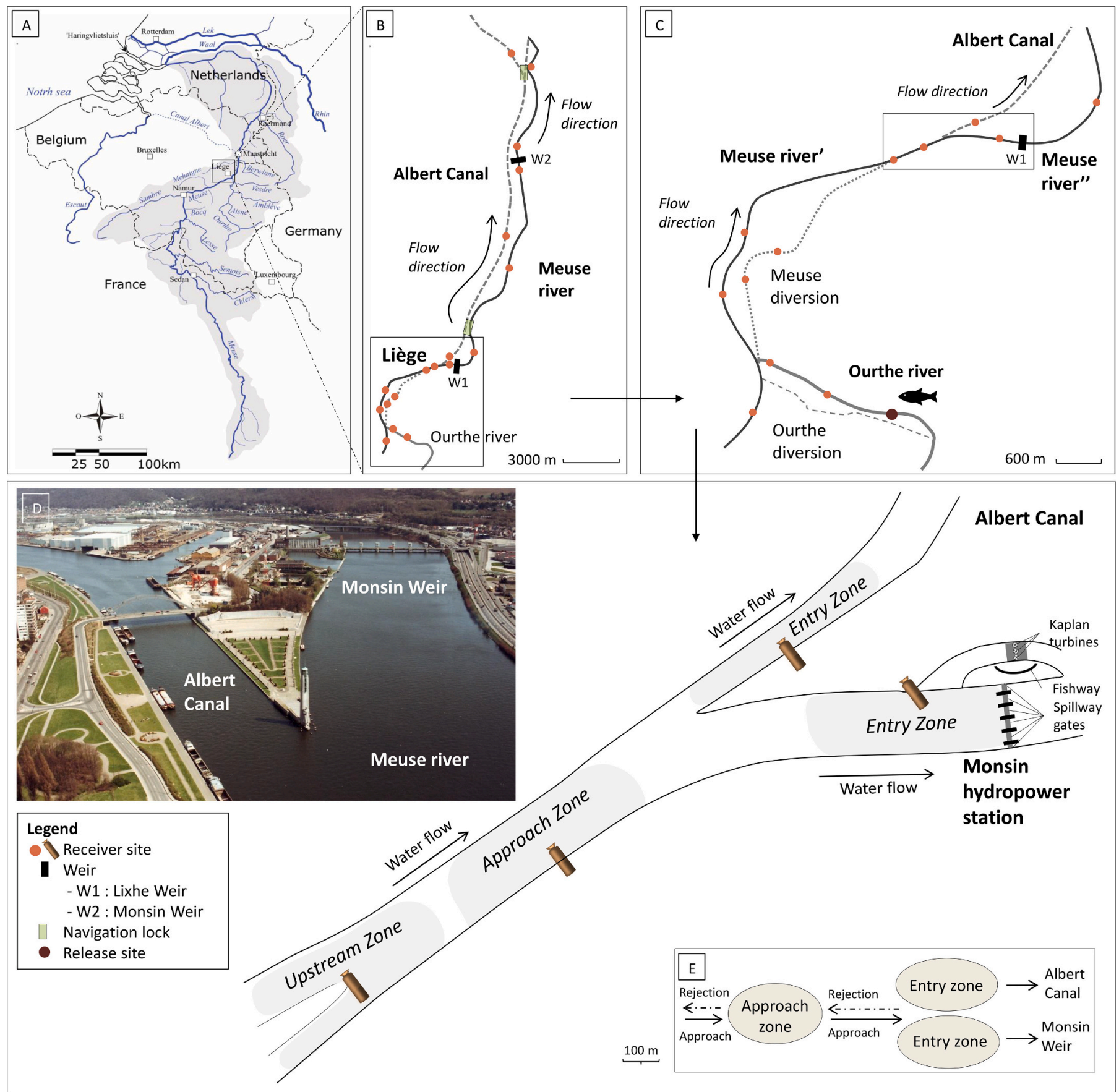

Fig. 1. Representation of the study site. (A) The international Meuse basin in France, Belgium, and The Netherlands. (B) The studied Meuse river and Albert Canal stretches with the locations of the most downstream acoustic receivers and two dams. (C) Meuse and Ourthe river stretches upstream of the Albert - Monsin site with the locations of the upstream acoustic receivers. (D) Photographic (@SPW-Direction des Voies Hydrauliques de Liège) and schematic representations of the Monsin hydropower station and the Albert Canal entrance. The study site is divided into four zones: the upstream zone, the approach zone, and the entry zones, which correspond to the detection area of 4 automatic receivers. (E) A schematic diagram showing the two entry zones (inspired by Nyqvist et al., 2017).

Downstream of the Lixhe hydropower station, there is still $323 \mathrm{~km}$ to the sea and seven migration barriers including two hydropower stations to cross. In the direction of the Albert Canal, $870 \mathrm{~m}$ upstream of the Monsin hydropower station, the distance to the sea is $129.5 \mathrm{~km}$. The Albert Canal is equipped with two navigation locks, enabling the smolts to go back to the Meuse river, $2 \mathrm{~km}$ (Monsin navigation lock) and $17 \mathrm{~km}$ (Lanaye navigation lock) downstream of the entrance of the Albert Canal (Fig. 1B). If the fish do not branch off in the Meuse river, they can continue towards the port of Antwerp. Smolts will have to pass six navigation locks and will also face several canal bifurcations that could disorient them. In the Antwerp harbour, downstream migrating smolts can use one of the three maritime locks to reach the Scheldt estuary or might eventually migrate through the Scheldt-Rhine canal up to Dutch estuaries.

We divided the hydropower/canal complex into two zones: the approach zone and two entry zones (Fig. 1D). To pass this complex and to select a migration route, the smolts enter the approach zone and may choose between the entry zone of the Albert Canal or the entry zone of the Monsin hydropower station or to move back upstream (Fig. 1E). After accessing an entry zone, a smolt can continue to migrate downstream or 


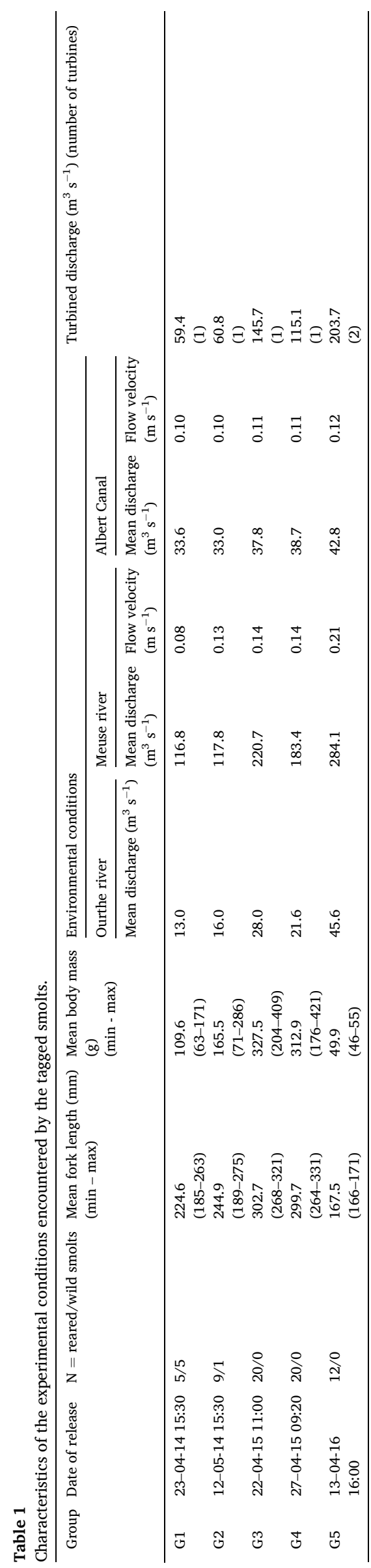

reject the zone by moving upstream.

\subsection{Smolts tagging}

We tagged a total of 72 one or two-years-old smolts during the three years of study (2014, 2015, and 2016). Sixty-six smolts came from the hatchery of Erezee (Public Service of Wallonia, Belgium) and six were captured at a bypass of the Mery hydropower station in the Ourthe river (description in Renardy et al., 2020). The hatchery-reared smolts had a mean fork length of $266.4 \mathrm{~mm}$ (range 166-331 mm) and a mean body mass of $238 \mathrm{~g}$ (range 46-286 g) (Table 1). The wild smolts had a mean fork length of $194.3 \mathrm{~mm}$ (range 185-208 mm) and a mean body mass of $72.3 \mathrm{~g}$ (range 63-88 g). The fork length and the body mass differed significantly between the hatchery-reared and wild smolts (Wilcoxon-Mann-Whitney tests, all $p<0.01$ ).

For tagging, the smolts were first anaesthetised with $0.2 \mathrm{~mL} \mathrm{1-1} \mathrm{of}$ eugenol, and after a $7 \mathrm{~mm}$ incision, they were surgically equipped with an acoustic transmitter in their body cavity (Vemco, Model Coded Tag V7; frequency $69 \mathrm{kHz}$; dimensions $7 \mathrm{~mm} \times 20.25 \mathrm{~mm}$; mass in water 0.7-1.0 g; expected lifetime 255 days). The incision was closed with two stitches using absorbable suture material (Renardy et al., 2020). After recovery, the tagged smolts were released into the Ourthe river.

\subsection{Smolts tracking}

The tagged smolts were divided into five groups (G1 to G5) spread over three years $(2014,2015$, and 2016) and released at different periods in order to have contrasting environmental conditions (Table 1). Over the three periods of tracking, the water discharge of the Meuse river varied from 43.3 to $454.9 \mathrm{~m}^{3} \mathrm{~s}^{-1}$ (Table 1). The five groups were released $1965 \mathrm{~m}$ upstream from the confluence between the Ourthe river and the Meuse river (Fig. 1C). The smolts were passively tracked with 18 acoustic receivers (Vemco, Model VR2W; identifiable frequency $69 \mathrm{kHz}$; dimensions $308 \mathrm{~mm} \times 73 \mathrm{~mm}$; mass in water $50 \mathrm{~g}$; battery expected lifetime 15 months), which were fixed at strategic locations in the study area and beyond from $1000 \mathrm{~m}$ downstream of the release site (Ourthe river) to 26,025 m (Meuse river) and 28,223 m (Albert Canal) downstream of the release site (Fig. 1B). The smolts were detected when they approached the acoustic receiver stations, at a distance of approximately $300 \mathrm{~m}$. The number of detections per smolt was 2536 on average.

\subsection{Smolt behavioural metrics}

The smolt detections in the receiver network enabled the definition of several quantitative behavioural metrics useful to describe smolts' migration upstream of the Albert Canal - Monsin site.

Travel time

Hourly time required by the smolts to move from one point to another corresponding to the time between the last detection at the first receiver and first detection at the second receiver.

Hesitation time

Hourly time between the first and last detection in a studied zone (upstream, approach and entry zones) spent by the smolts before swimming downstream or upstream (Fig. 1D).

Arrival delay in reaching the approach zone

Hourly time needed for acoustically tracked individual smolts to reach the approach zone of the hydropower/canal complex. This travel time corresponds to the time between the release time and the first detection in the approach zone.

Approach zone detection rate

Number of recorded detections in the approach zone for each smolt (Fig. 1D).

Passage attempt

Movement of smolts from the approach zone to one of the entry zones (Fig. 1D).

Passage time 
The last recorded detection (local hour) of the smolts in the entry zones before passing the hydropower/canal complex and indication of the period of the day (dusk, night, sunrise, and day).

\section{Research time}

Time required by the smolts to pass through the hydropower/canal complex. This corresponds to the time spent upstream of the site between the first location in the approach zone and last location in the entry zones (Fig. 1D).

\section{Migration route used}

The percentage of individual smolts using each migration route at the hydropower/canal complex in comparison with the tagged smolts that approached the site.

\subsection{Hydrodynamic numerical modelling}

Numerical modelling of the hydrodynamic conditions during the survey periods was performed using the WOLF2D software developed by the HECE research group at Liège University for more than 20 years. This software solves the depth-integrated shallow water equations on a Cartesian grid using a finite volume technique (Erpicum et al., 2009, 2010a).

The model was applied to the survey site depicted in Fig. 1, which was extended upstream and downstream to include gauging stations locations where boundary conditions can be prescribed. Bathymetry data were gained from a high-resolution digital elevation model with a $1 \mathrm{~m}$ horizontal resolution and $0.15 \mathrm{~m}$ vertical accuracy (Erpicum et al.,
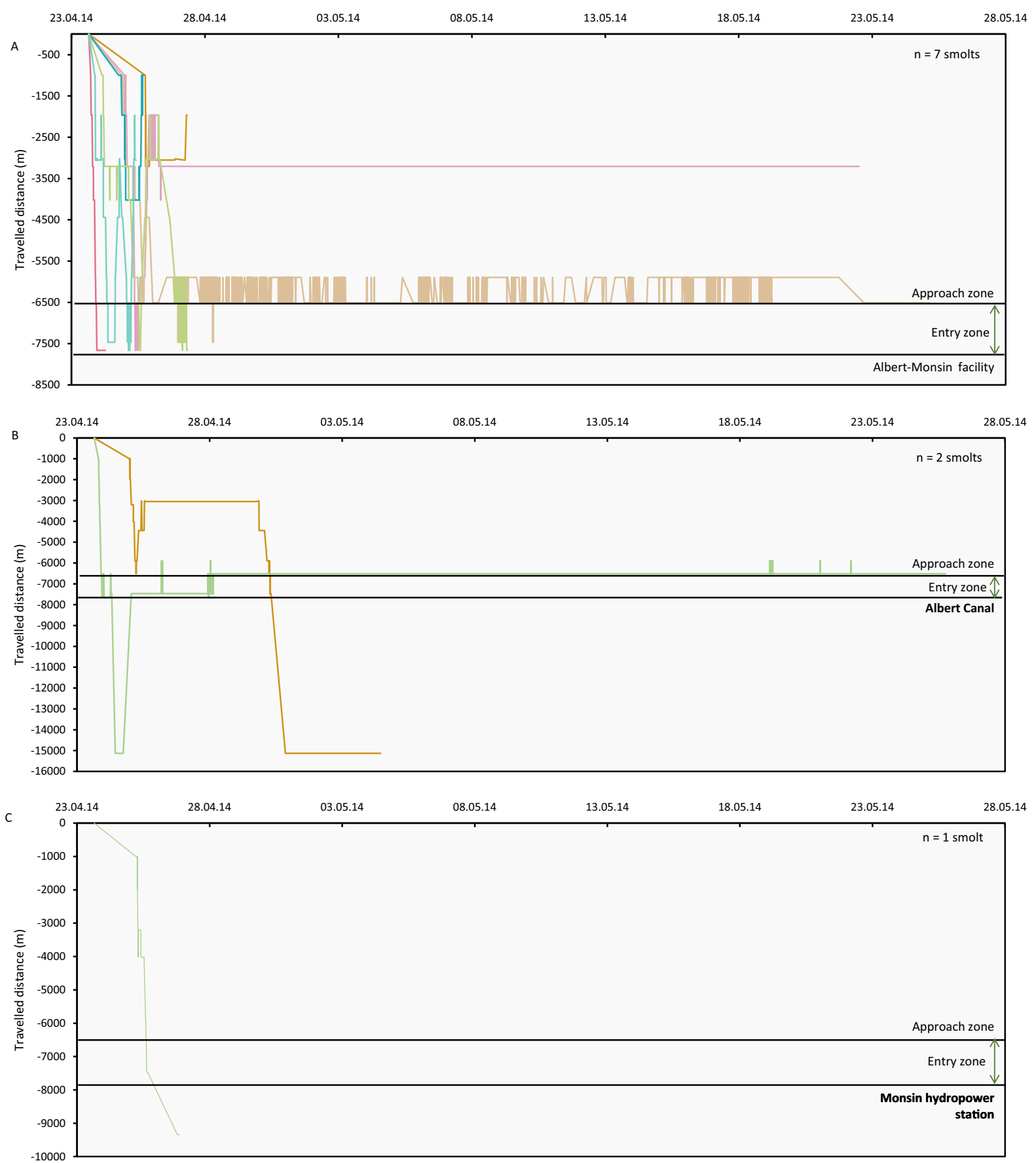

Fig. 2. Smolts migration patterns of the first release (G1). (A) Smolts that did not cross the Albert - Monsin site. (B) Smolts that migrated by the Albert Canal. (C) Smolts that migrated by the Meuse river. 
2010b). The model was extended $8.6 \mathrm{~km}$ upstream in the Meuse river and 7.1 downstream of Liege in the Albert Canal to reach two gauging stations (the extreme parts of the modelled area are not represented in Fig. 1). The measured discharge was imposed as a boundary condition at these two locations and also in the Ourthe river. At Monsin, the discharge through the turbines was prescribed, while a constant water level boundary condition was used at the dam gates. The numerical model covered a total of $34.1 \mathrm{~km}$ of river stretches close to Liège in the Meuse and the Ourthe rivers and the Albert Canal.

Two sets of simulations were performed: a first one in hypothetical steady-state conditions with constant discharges in the Meuse river from 50 to $400 \mathrm{~m}^{3} \mathrm{~s}^{-1}$ with a step of $50 \mathrm{~m}^{3} \mathrm{~s}^{-1}$ and a mean constant discharge of $44 \mathrm{~m}^{3} \mathrm{~s}^{-1}$ in the Albert Canal. These values cover the whole range of discharge conditions observed during the telemetry surveys. The second set of simulations considered the real transient flow conditions faced by the smolts during the telemetry surveys using hourly basis records of discharges and water levels at the model boundaries.

Hydrodynamic results were analysed in terms of the averaged discharge and flow velocity, temporal velocity gradient and flow orientation in each automatic receiver estimated detection zone and during each smolt detection period.

\subsection{Statistical analyses}

Because the data violated the assumptions of normality (Kolmogorov-Smirnov, $p<0.05$ ), non-parametric tests were used. To test the difference of the ratio of upstream and downstream movements between the groups, a Pearson's $\chi^{2}$ test was used. The approach behaviour of tagged smolts described by travel time, migration speed and hesitation time was analysed and compared between the groups and the years by using Kruskal-Wallis (KW) tests and Mann-Whitney (U) tests. To observe the effects of water discharge $\left(\mathrm{m}^{3} \mathrm{~s}^{-1}\right)$ and flow velocity $\left(\mathrm{m} \mathrm{s}^{-1}\right)$ on the approach zone detection rate, we used Spearman correlations, and on passage attempts, we used $U$ tests. The behaviour described by the approach zone detection rate, passage attempts, the research time, and the time spent in the entry zones was compared between the smolts that passed the site and those that did not with $\mathrm{U}$ tests. The effect of water discharge was tested with a Spearman correlation. The repartition of migration routes used by the smolts was compared between the years by using a Pearson's $\chi^{2}$ test. The effects of water discharge and flow velocity on the migration route used were highlighted by using $\mathrm{U}$ tests. The migration speed was compared between the stretches, the groups and the years by using KW tests. All statistical analyses were performed using the software R (version 3.4.2), and the significance level was set at $p=$ 0.05 .

\section{Results}

\subsection{Description of the general migration patterns}

In $2014,95 \%$ ( $n=19 / 20$ ) of the released smolts ( $G 1=10 / 10 \& \mathrm{G} 2$ $=9 / 10$ ) started their downstream migration (Figs. 2, 3, \& 7). After reaching the Meuse river, downstream of the confluence with the Ourthe river, $42.1 \%$ of the smolts ( $G 1=4 / 10 \& \mathrm{G} 2=4 / 9$ ) expressed hesitation behaviour by performing several back and forth movements, and sometimes even over long distances (up to $7 \mathrm{~km}$ ). Of the smolts, $73.7 \%$ ( $\mathrm{G} 1=8 / 10 \& \mathrm{G} 2=6 / 9$ ) were recorded in the approach zone and $68.4 \%$ $(\mathrm{G} 1=8 / 10 \& \mathrm{G} 2=5 / 9)$ entered at least one of the two entry zones

A
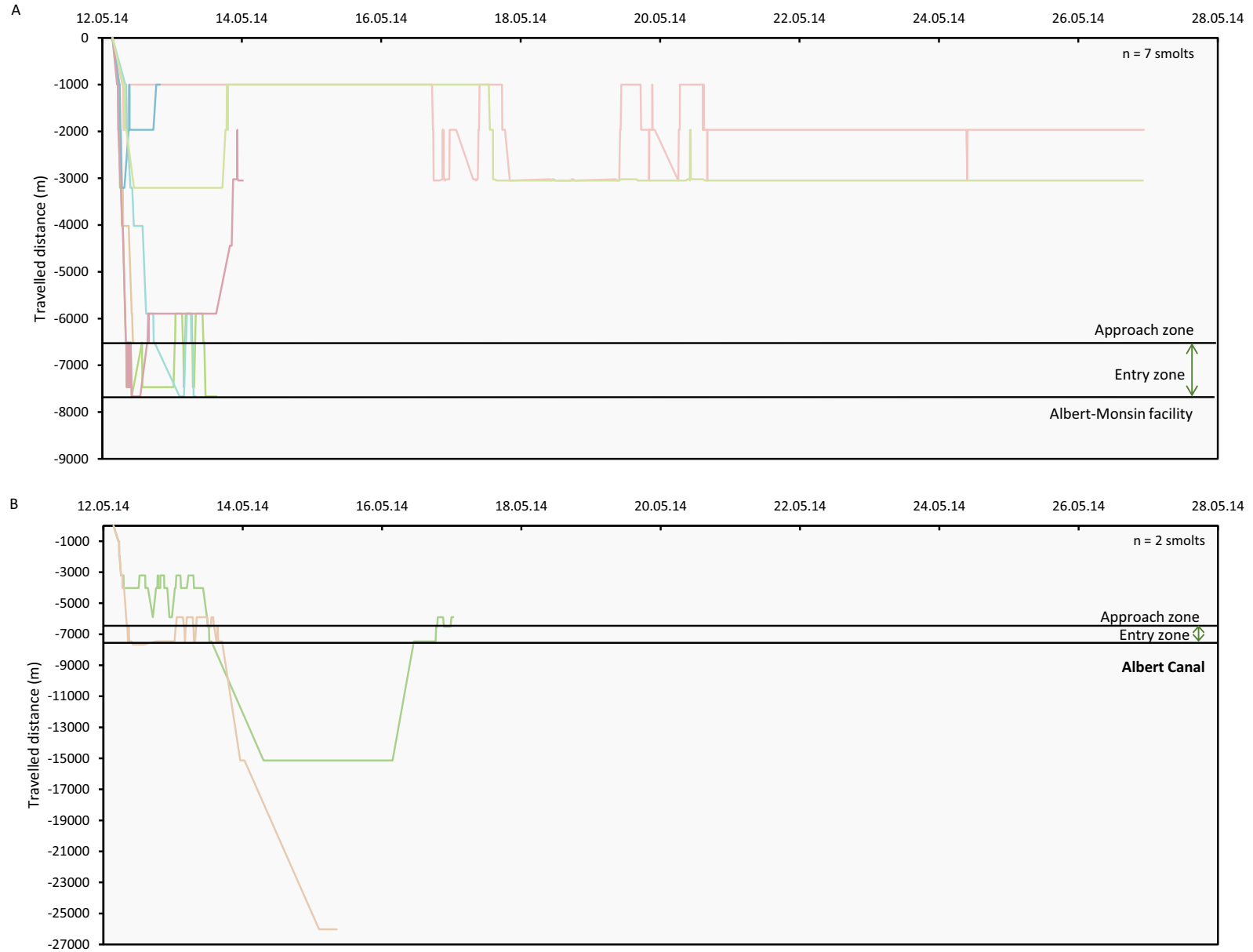

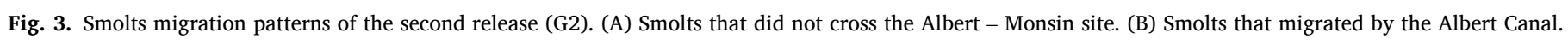



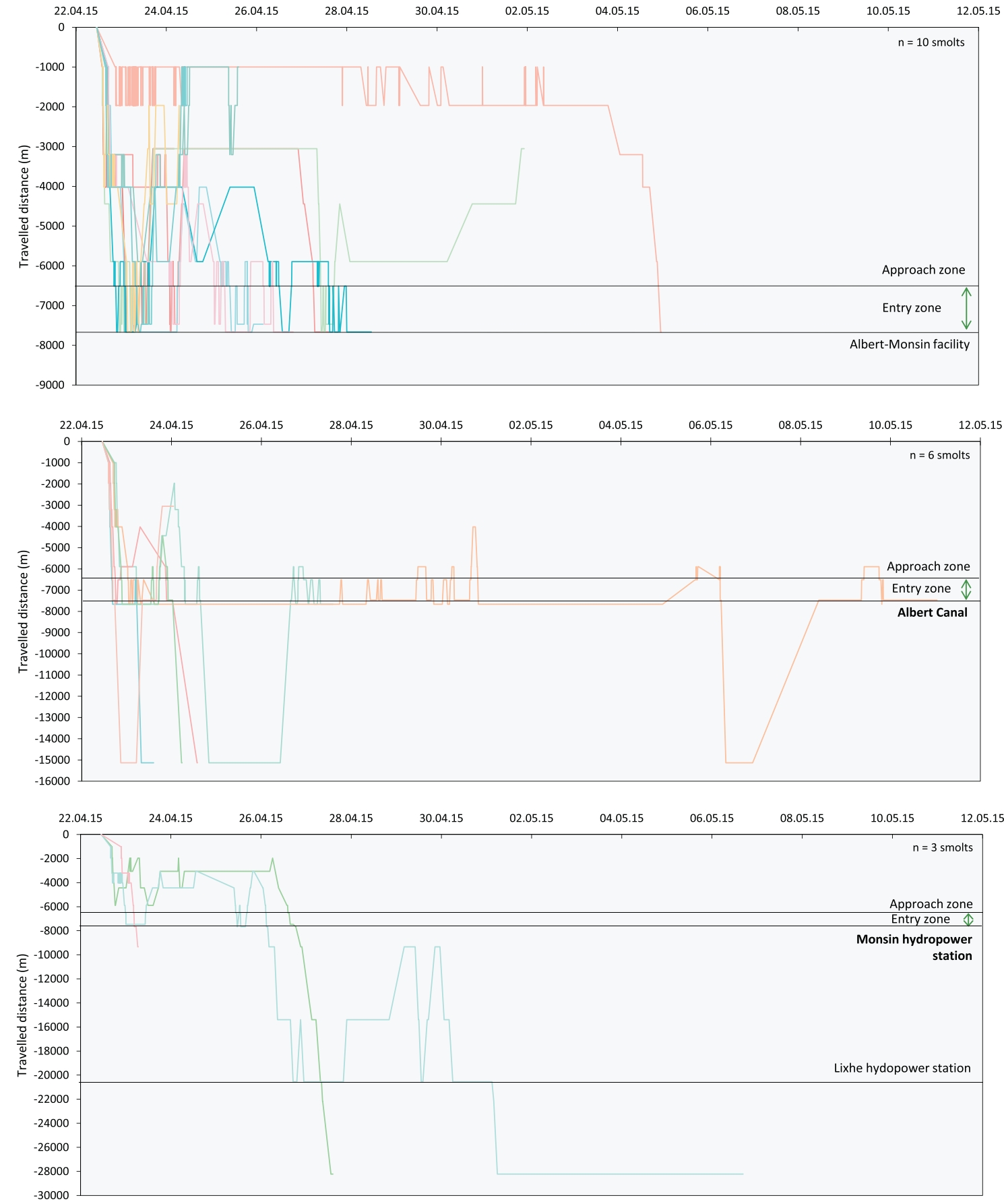

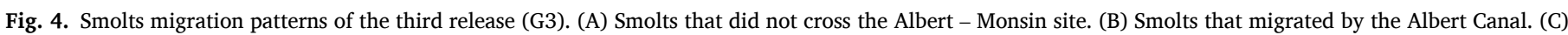
Smolts that migrated by the Meuse river.

(Fig. 7). Once in the entry zones, $64.5 \%$ of the smolts (G1 $=5 / 8 \& \mathrm{G} 2=$ $3 / 5$ ) expressed several back and forth movements between one of the entry zones and the approach zone. Only $23 \%(\mathrm{G} 1=2 / 8 \& \mathrm{G} 2=1 / 5)$ of the smolts passed through the hydropower/canal complex, among which two smolts (G1 $=1 / 8 \&$ G2 $=1 / 5)$ used the Albert Canal, one used the Monsin navigation lock to the Meuse river and one smolt via the hydropower station $(\mathrm{G} 1=1 / 8)$ (Fig. 7). Out of the smolts that did not pass, $20 \%(\mathrm{G} 3=1 / 6 \& \mathrm{G} 4=1 / 4)$ entered the Albert Canal but around $15,000 \mathrm{~m}$ downstream of the release site, they turned back to move upstream.

In 2015, $92.3 \%$ of the smolts $(n=37 / 40)$ started their downstream migration (G3 $=20 / 20 \& \mathrm{G} 4=17 / 20$ ) (Figs. $4,5, \& 7)$, and $43.2 \%$ (G3
$=11 / 20 \& \mathrm{G} 4=5 / 17)$ expressed hesitation behaviour after entering the Meuse river by moving frequently back and forth. Among the 37 smolts, $8.1 \%(\mathrm{G} 3=2 / 20 \& \mathrm{G} 4=1 / 17)$ stopped their migration probably due to exhaustion or disorientation before entering the approach zone (Fig. 7). Eighty-nine per cent (G3 $=17 / 20 \& \mathrm{G} 4=16 / 17$ ) were recorded in the approach zone and in the entry zones (Fig. 7), among which $60.6 \%$ (G3 = $12 / 17 \&$ G4 $=8 / 16$ ) expressed several back and forth movements. Among the 33 smolts, $36.4 \%$ ( $\mathrm{G} 3=6 / 17 \& \mathrm{G} 4=6 / 16$ ) passed through the complex: five by the Albert Canal ( $\mathrm{G} 3=3 / 6 \& \mathrm{G} 4=2 / 6$ ) and seven by the Monsin hydropower station ( $\mathrm{G} 3=3 / 6 \& \mathrm{G} 4=4 / 6$ ) (Fig. 7). Among the seven smolts that migrated by the Meuse river, five smolts ( $\mathrm{G} 3=2 \& \mathrm{G} 4=3$ ) crossed the Lixhe hydropower station and four 

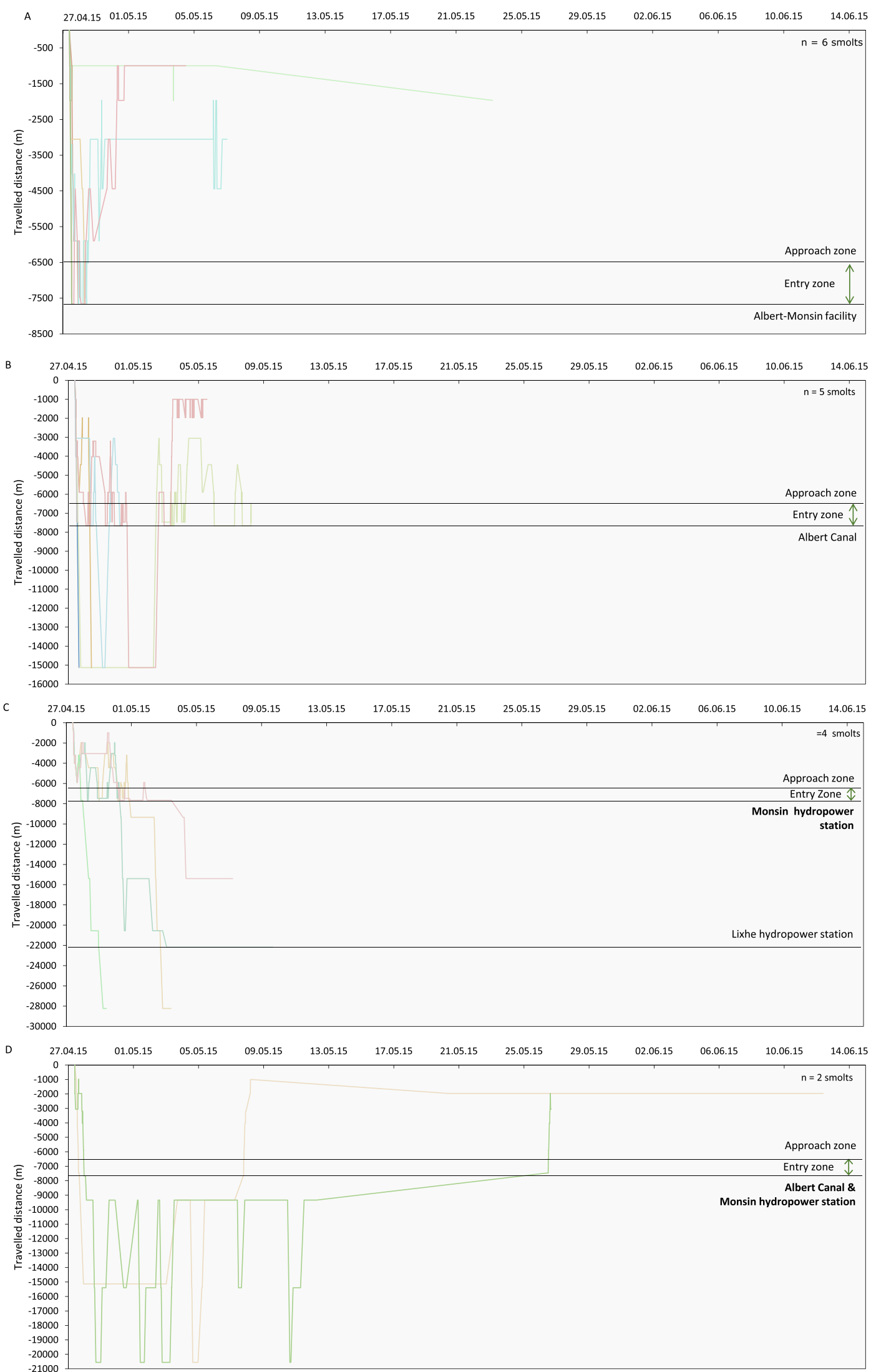

Fig. 5. Smolts migration patterns of the fourth release (G4). (A) Smolts that did not cross the Albert - Monsin site. (B) Smolts that migrated by the Albert Canal. (C) Smolts that migrated by the Meuse river. (D) Smolts that migrated by both the Meuse river and the Albert Canal. 

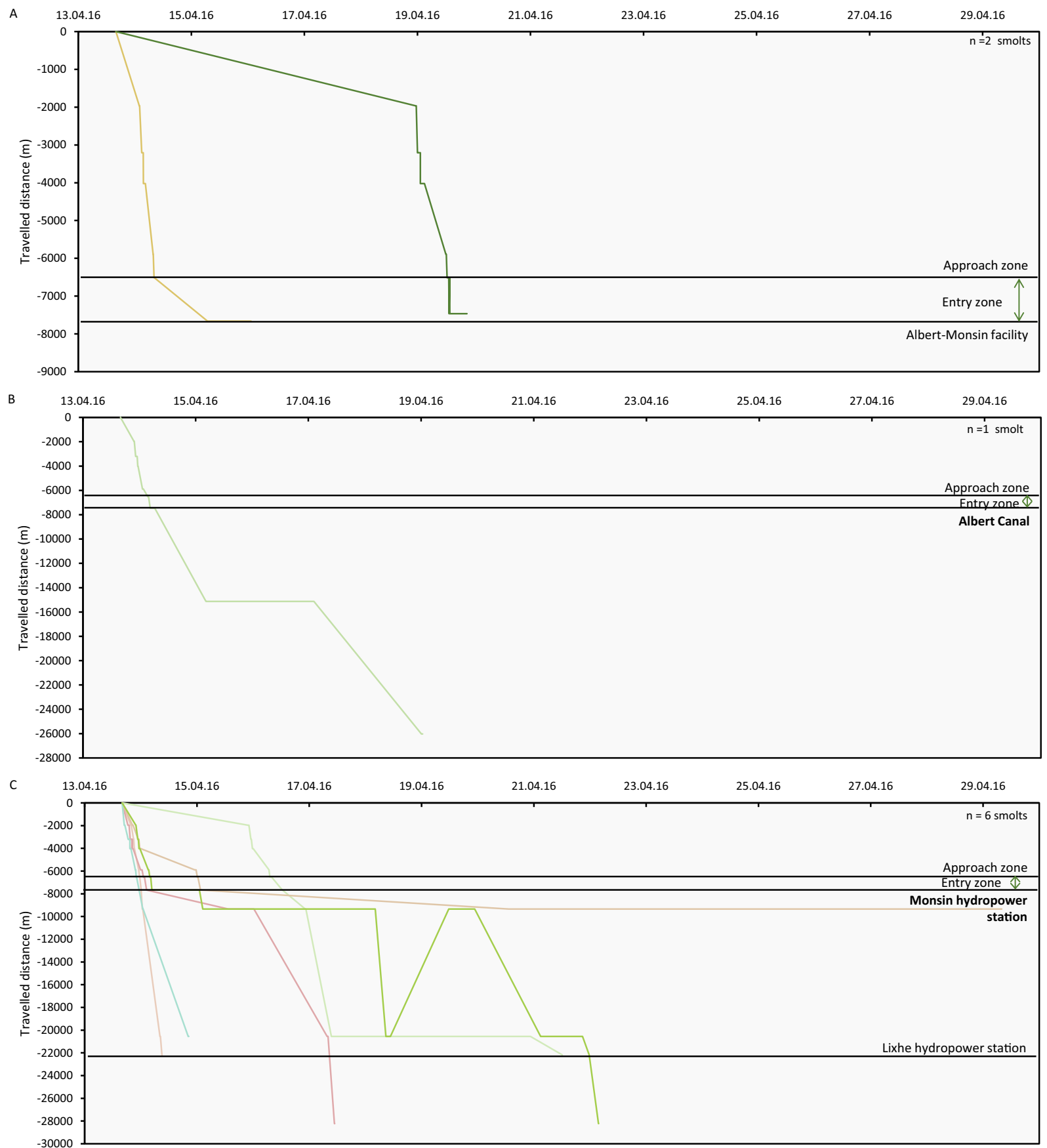

Fig. 6. Smolts migration patterns of the fifth release (G5). (A) Smolts that did not cross the Albert - Monsin site. (B) Smolts that migrated by the Albert Canal. (C) Smolts that migrated by the Meuse river.

continued their migration ( $\mathrm{G} 3=2 \& \mathrm{G} 4=2$ ) (Fig. 7). Regarding the other $67.6 \%$ of smolts ( $\mathrm{G} 3=14 / 20 \& \mathrm{G} 4=11 / 17$ ) that did not pass through the site, $18.9 \%(G 3=3 / 20 \& \mathrm{G} 4=4 / 17)$ migrated to the Albert Canal around 15,000 $\mathrm{m}$ downstream of the release site. Among these smolts, six turned back upstream to the approach zone and one reached the Meuse river and turned back upstream to the Monsin hydropower station.

In 2016, 75\% ( $n=9 / 12)$ of the smolts of the G5 initiated their downstream migration and were rapidly recorded in the approach and entry zones (Figs. 6 \& 7). Only one performed a few back and forth movements before approaching the hydropower/canal complex. Among the nine smolts, $77.8 \%(n=7 / 9)$ passed through the Albert - Monsin site without back and forth movements, six by the Monsin hydropower station, and one by the Albert Canal (Fig. 7). Among the six smolts that migrated by the Meuse river, four crossed the Lixhe hydropower station, and two continued their migration (Fig. 7). The other $22.2 \%$ of smolts did not pass through the site $(n=2 / 9)$.

\subsection{Migration speed, hesitation time, and choice of migration route}

Of the 72 released smolts of the five groups during the three years, $90.3 \%(\mathrm{G} 1=10 / 10, \mathrm{G} 2=9 / 10, \mathrm{G} 3=20 / 20, \mathrm{G} 4=20 / 20 \& \mathrm{G} 5=9 / 12)$ started their downstream migration at a median speed of $0.14 \mathrm{~m} \mathrm{~s}^{-1}$ and reached the confluence with the Meuse river with a median travel time of 04:02 (range 00:15-127:14) $(n=64)$ (Table 2 \& Fig. 8). Given the groups, the migration speed in the Ourthe river differed significantly 


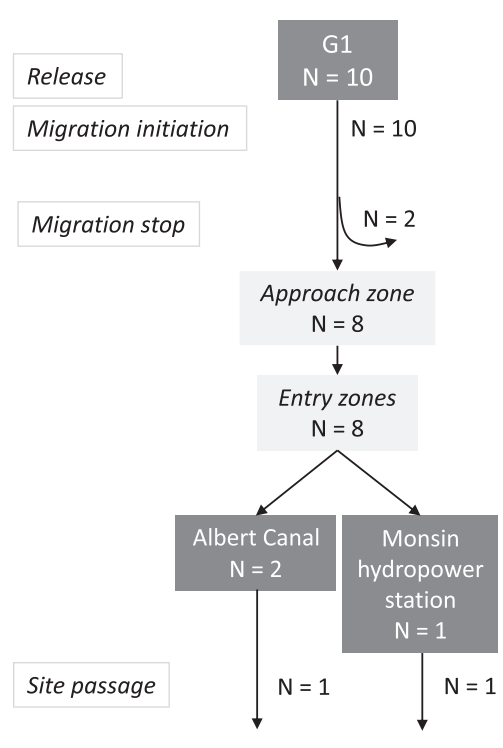

Site passage
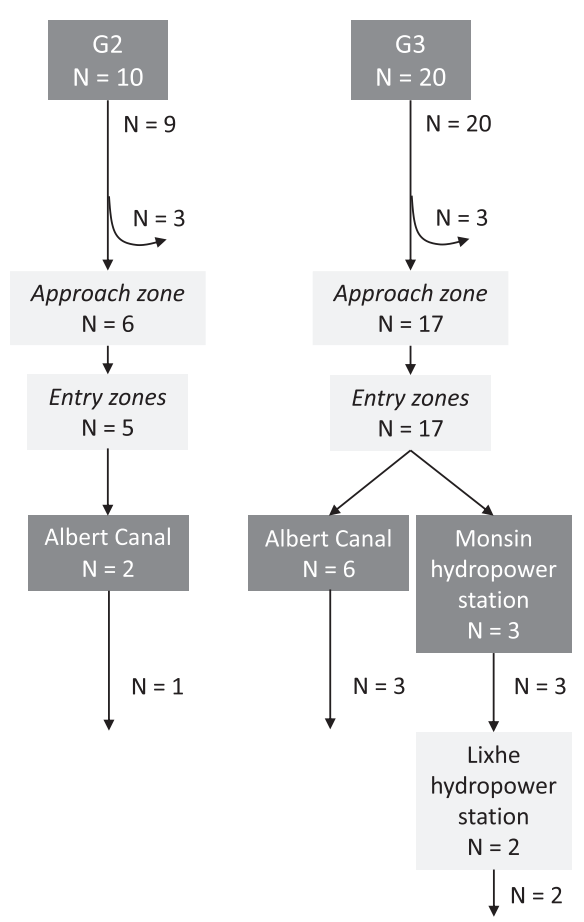

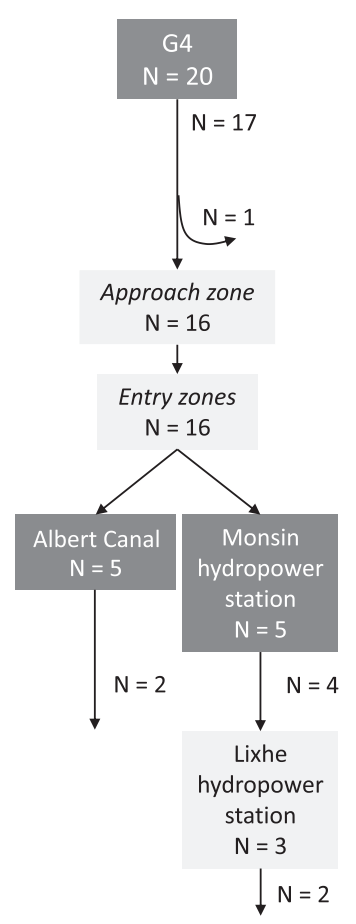

Fig. 7. Overview of smolts migration patterns of all groups (G1, G2, G3, G4, \& G5) over the entire studied stretch.

Table 2

Downstream migration speed of the smolts in the different stretches of the river.

\begin{tabular}{|c|c|c|c|c|}
\hline & \multicolumn{4}{|c|}{ Migration speed $\left(\mathrm{m} \mathrm{s}^{-1}\right)$} \\
\hline & 2014 & 2015 & 2016 & Mean \\
\hline Ourthe river & $\begin{array}{l}0.13 \\
(0.01-0.28)\end{array}$ & $\begin{array}{l}0.16 \\
(0.03-2.18)\end{array}$ & $\begin{array}{l}0.1 \\
(0.004-0.59)\end{array}$ & 0.14 \\
\hline $\begin{array}{l}\text { Meuse river' } \\
\text { (upstream Meuse } \\
\text { river) }\end{array}$ & $\begin{array}{l}0.21 \\
(0.04-0.69)\end{array}$ & $\begin{array}{l}0.16 \\
(0.04-0.97)\end{array}$ & $\begin{array}{l}0.21 \\
(0.05-0.35)\end{array}$ & 0.17 \\
\hline $\begin{array}{l}\text { Meuse river" } \\
\text { (downstream Meuse } \\
\text { river) }\end{array}$ & 0.02 & $\begin{array}{l}0.09 \\
(0.02-0.42)\end{array}$ & $\begin{array}{l}0.05 \\
(0.0003-0.45)\end{array}$ & 0.14 \\
\hline Albert Canal & $\begin{array}{l}0.08 \\
(0.02-0.13)\end{array}$ & $\begin{array}{l}0.39 \\
(0.16-0.87)\end{array}$ & 0.1 & 0.20 \\
\hline
\end{tabular}

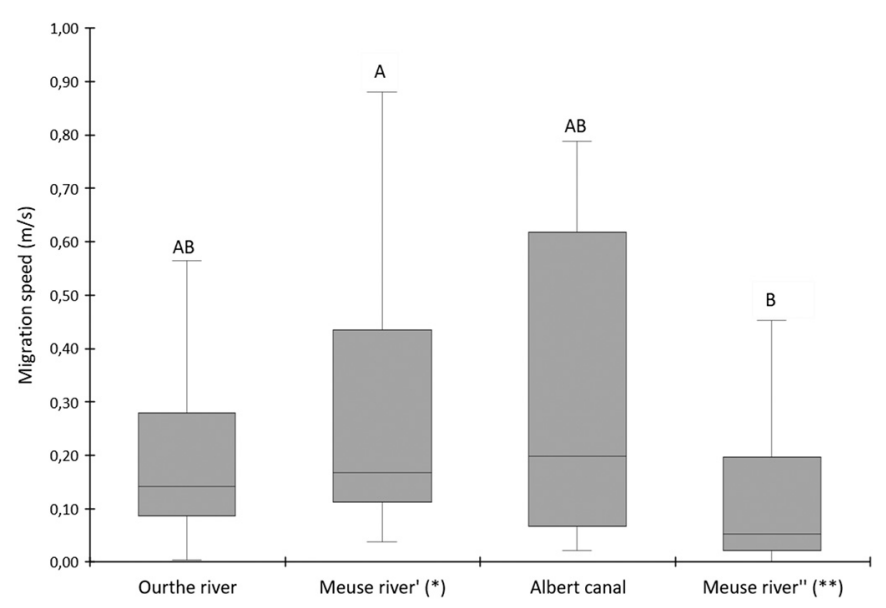

Fig. 8. Smolts migration speed in the Ourthe river, upstream, and downstream of the Albert - Monsin site. (*) Meuse river upstream \& (**) downstream of the hydropower/canal complex. Values sharing at least one common superscript (a or b) do not differ at the 0.05 level of significance (KW test, $p=0.02$ ).
(KW test, $\mathrm{df}=4, p<0.0001$ ), with the highest median speed of $0.43 \mathrm{~m}$ $\mathrm{s}^{-1}$ for $\mathrm{G} 4$.

At the confluence with the Meuse river, smolts performed more or fewer back and forth movements, depending on the water discharge and flow velocities (Fig. 9). The mean Meuse water discharge varied from $116.8 \mathrm{~m}^{3} \mathrm{~s}^{-1}$ for $\mathrm{G} 1$ to $284.1 \mathrm{~m}^{3} \mathrm{~s}^{-1}$ for G5. At water velocities below $0.15 \mathrm{~m} \mathrm{~s}^{-1}$, the smolts seemed to be disoriented by performing more upstream movements (Fig. 9B). The tendency to move downstream was favoured when the flow velocity was greater than $0.15 \mathrm{~m} \mathrm{~s}^{-1}$ and the downstream movements were even more pronounced at a flow velocity over $0.2 \mathrm{~m} \mathrm{~s}^{-1}$ (Fig. 9A).

Despite a gradual increase of the Meuse water discharge and flow velocities (Table 1), the proportions of downstream and upstream movements were similar for G1, G2, G3, and G4 (Pearson's $\chi 2, p=0.34$ ) and did not differ significantly from a random distribution (Pearson's $\chi 2, p>0.11$ ) (Fig. 10). However, for G5, the elevated water discharge and flow velocity (Table 1) stimulated the smolts to migrate downstream, which differed significantly from a random distribution (Pearson's $\chi 2, p<0.0001$ ).

Once in the Meuse river, $86.2 \%$ of the smolts $(n=57 / 65)$ migrated downstream at a median speed of $0.17 \mathrm{~m} \mathrm{~s}^{-1}(\mathrm{n}=57)$ and took a median travel time of 07:30 to reach the approach zone, $6513 \mathrm{~m}$ downstream of the release site and upstream of the hydropower/canal complex (Table 2 \& Fig. 8). The speed did not differ between groups (KW test, $\mathrm{df}=4, p=$ 0.76 ) or years (KW test, $\mathrm{df}=2, p=0.94$ ). The median arrival delay in reaching the approach zone was 13:43. With a median research time of 04:45 (range 00:33-473:16), only 38.6\% $(n=22 / 57)$ passed through the hydropower/canal complex.

Out of the 14 smolts that migrated by the Meuse river", 10 reached the Lixhe hydropower station with a median speed of $0.14 \mathrm{~m} \mathrm{~s}^{-1}(n=$ 10) (Table $2 \&$ Fig. 8) and nine took a median research time of 10:48 (range 00:10-145:50) to cross the Lixhe hydropower station (situation in Fig. 1). In the Albert Canal, the median migration speed was $0.20 \mathrm{~m}$ $\mathrm{s}^{-1}$ (Table $2 \&$ Fig. 8). The median migration speed of the smolts from the release site to the most downstream detection was $0.11 \mathrm{~m} \mathrm{~s}^{-1}$ (range $0.001-0.79 \mathrm{~m} \mathrm{~s}^{-1}$ ), but the migration speed differed significantly between the stretches (KW test, $\mathrm{df}=2, p=0.02$ ). Between the Meuse river' and the Meuse river", the speed was significantly higher in the upstream 

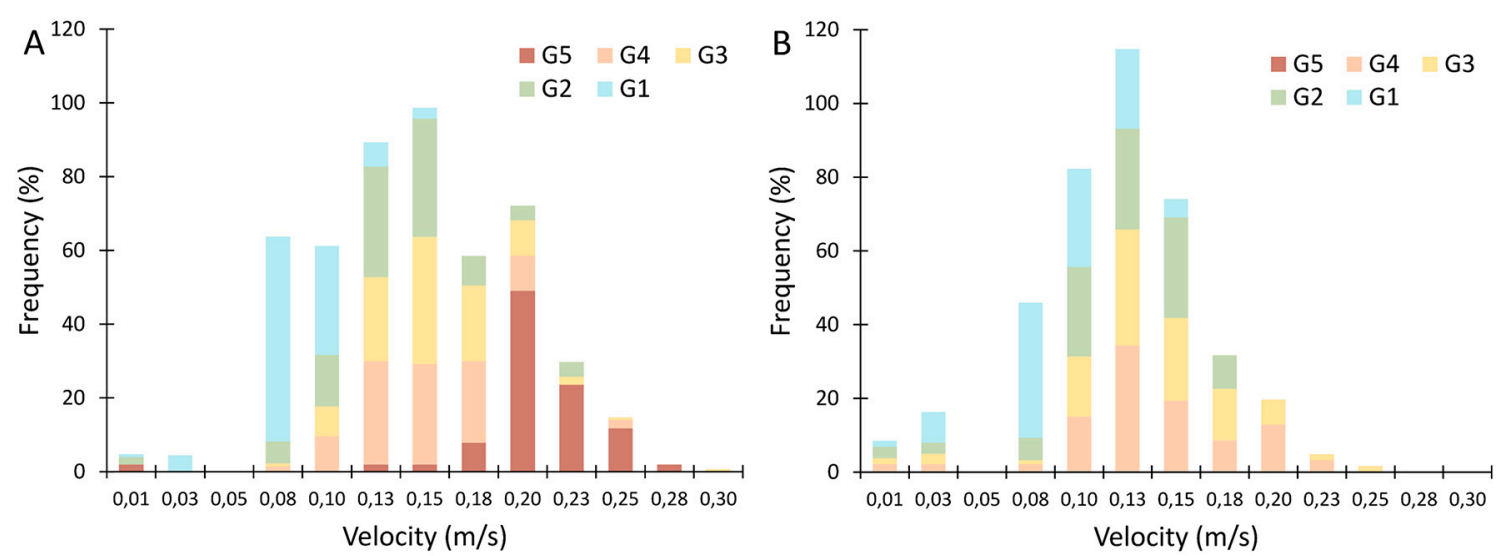

Fig. 9. Frequency distributions of flow velocities faced when the smolts choose to swim (A) downstream and (B) upstream.
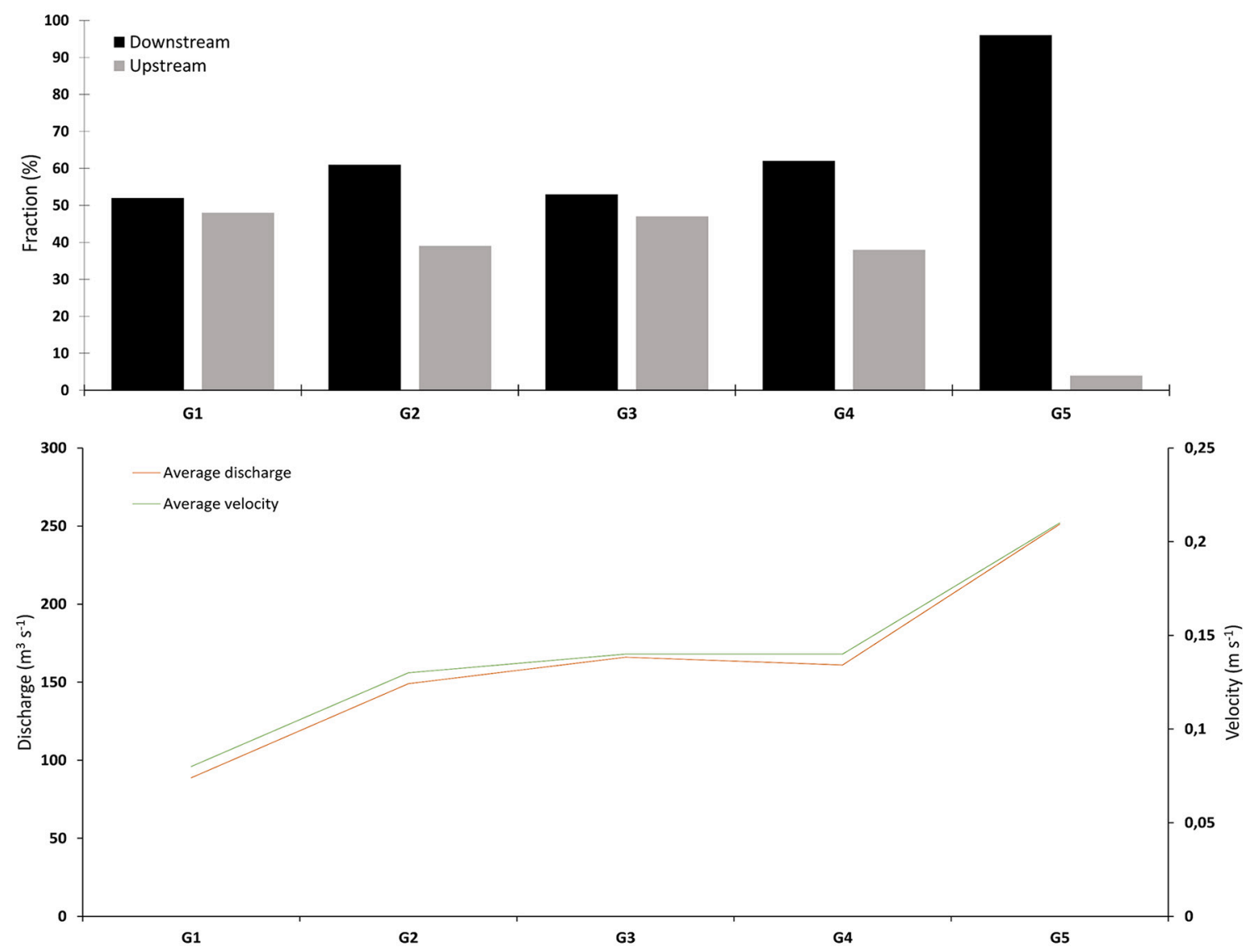

Fig. 10. Smolts' swimming orientations for each group (top) and associated average water discharge and flow velocity (bottom).

zone than downstream ( $U$ test, $p<0.01$ ) (Fig. 8).

\subsection{Fine-scale behaviour of smolts at the hydropower/canal complex}

Among the 57 smolts detected in the approach zone, 56.1\% were during dusk or the night (respectively: $\mathrm{n}=10$ and $\mathrm{n}=22), 14 \%(n=8)$ during sunrise, and 29.9\% $(n=17)$ during the day (Fig. 11A). The distribution of detections between the four categories (dusk, night, sunrise, and day) was not significantly different from a random distribution (Pearson's $\chi 2, p=0.23$ ). Comparing the migration period of the smolts between the groups, a significant difference was observed (Pearson's $\chi 2, p<0.0001$ ), probably due to the time of release.

Before entering the approach zone, the smolts spent a median hesitation time of 00:12 in the upstream zone (Fig. 12). In the approach zone, the median number of detections was five (range 1-474). The Meuse water discharge and velocities had an effect on the approach zone detection rate (Spearman's correlation, both: Rho $=-0.49, p<0.001$ ). An increase in the water discharge or water velocities in the approach zone was associated with fewer detections and therefore a reduction of back and forth movements. At every detection in the approach zone, the smolts made a passage attempt after a median hesitation time of 00:10 (Fig. 12), by the Albert Canal or the Monsin hydropower station, or returned towards the upstream zone; $54.4 \%(n=31 / 57)$ of the smolts first approached the Monsin hydropower station, 36.8\% ( $n=21 / 57)$ approached the Albert Canal, and $8.8 \%(\mathrm{n}=5)$ moved back to the upstream zone without entering the entry zones. Fifty-six smolts were 

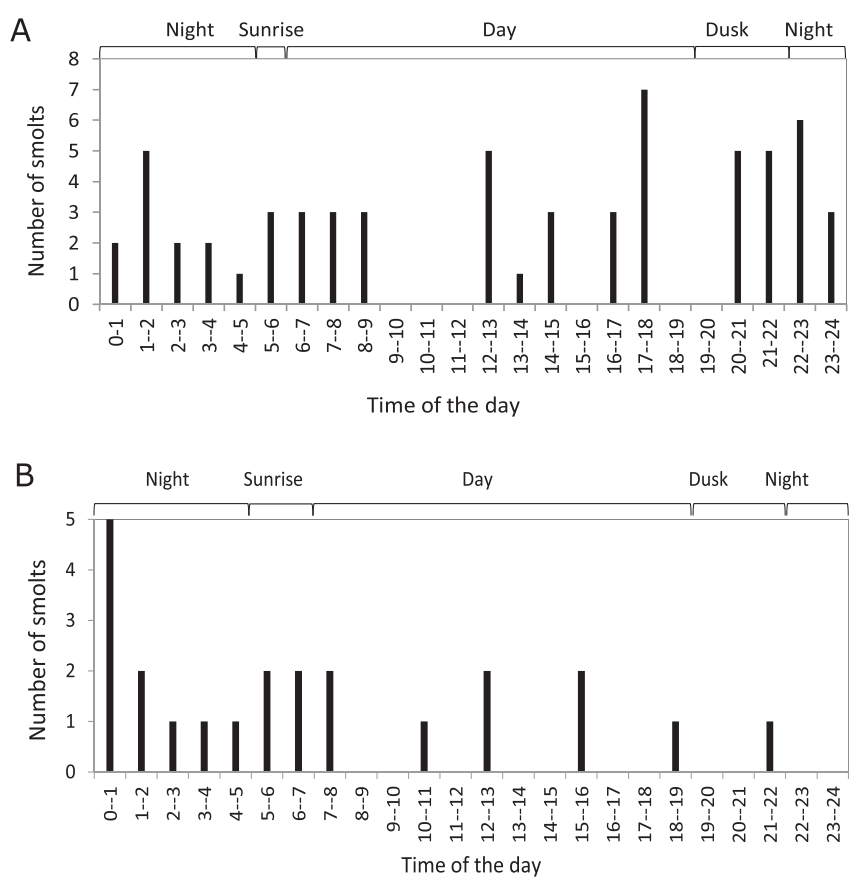

Fig. 11. A) First detection of the smolts in the approach zone according to the time of day. B) The passage of the Albert - Monsin site by the smolts according to the time of day.

detected in the entry zones and expressed a median of three passage attempts (range 1-36). The smolts expressed a median hesitation time of 00:38 upstream of the Monsin hydropower station and 00:20 at the entrance of the Albert Canal (Fig. 12). For the first passage attempt, $55.4 \%$ of the smolts $(\mathrm{n}=31 / 56)$ followed the main flow, of which two smolts approached the Albert Canal, and 29 smolts approached the Monsin hydropower station. For the last passage attempt, $58.9 \%$ of the smolts $(n=33 / 56)$ followed the main flow, of which two smolts approached the Albert Canal, and 31 smolts approached the Monsin hydropower station. Considering all the choices expressed by the smolts in the approach zone, $37 \%$ were passage attempts towards the hydropower station and $36 \%$ towards the Albert Canal. The remaining $28 \%$ of choices were to return upstream of the approach zone.

Passage attempts towards a migration route were influenced by the Meuse water discharge ( $U$ test, $p<0.0001$ ). The flow velocity in the approach zone and the flow velocity ratio between the Monsin station and Albert Canal had an effect on passage attempts towards a migration route too (U test, respectively: $p<0.0001 \& p<0.001$ ). An increase of Meuse water discharge induces a change of water flow direction towards the Monsin hydropower station with a gradual acceleration of the flow velocity (Fig. 13).

Passage attempts via the Monsin hydropower station were associated with a median approach zone water discharge of $161 \mathrm{~m}^{3} \mathrm{~s}^{-1}$, a median flow velocity of $0.14 \mathrm{~m} \mathrm{~s}^{-1}$, and a median velocity ratio of 0.92 ; whereas by the Albert Canal, the associated median approach zone water discharge was $132 \mathrm{~m}^{3} \mathrm{~s}^{-1}$, the median flow velocity was $0.11 \mathrm{~m} \mathrm{~s}^{-1}$, and the median velocity ratio was 0.69 (Figs. $13 \& 14$ ). Between 0.1 and $0.14 \mathrm{~m} \mathrm{~s}^{-1}$, which corresponds to a simulated water discharge varying between 150 and $200 \mathrm{~m}^{3} \mathrm{~s}^{-1}$ (Fig. 13), the smolts performed passage attempts towards both migration routes with similar frequencies (Fig. 14). The flow velocity in the Albert Canal also affected smolts' migration behaviour (Pearson's $\chi 2, p<0.0001$ ). Eighty-eight per cent of the canal outputs to the approach zone were associated with a flow velocity below $0.15 \mathrm{~m} \mathrm{~s}^{-1}$, and even sometimes associated with a negative flow velocity.

Among the 57 smolts detected in the approach zone, 38.6\% $(n=22$ / 57) passed through the hydropower/canal complex, of which $36.4 \%$ ( $n$ $=8)$ migrated by the Albert Canal, and $63.6 \%(n=14)$ by the Monsin hydropower station. Depending on the year, the proportions of the migration routes used differed significantly (Pearson's $\chi 2, p=0.04$ ), with a greater use of the Albert Canal in 2014, a balanced use between the Albert Canal and the Monsin hydropower station in 2015, and a greater use of the hydropower station in 2016. For nearly half of the smolts (45.4\%), the passage time was during dusk or the night (respectively: $\mathrm{n}=1$ and $n=9), 18.2 \%(n=4)$ during the sunrise, and $36.4 \%$ (n $=8$ ) during the day (Fig. 11B). The distribution of detections between the four categories (dusk, night, sunrise, and day) was not significantly different from a random distribution (Pearson's $\chi 2, p=0.79$ ). The median research time required to find a migration route was 04:45 (range 00:33-473:16). This differs slightly from the time spent by the smolts that did not cross the site, upstream of the complex ( $U$ test, $p=0.046$ ). The smolts that did not pass the complex spent a median time of 23:23 (range 00:10-432:05). The research time varied significantly with the Meuse water discharge (Spearman's correlation, both: $\mathrm{Rho}=-0.43, p=$ 0.045 ), with a reduction of the required research time associated with an increase of water discharge.

Of the 57 smolts detected in the approach zone, $61.4 \%(n=35 / 57)$ were not recorded downstream of the site, of which $7 \%(n=4)$ were last recorded in the entrance of the Albert Canal, and 24.6\% ( $n=14)$ upstream of the Monsin hydropower station. The approach zone detection rate and the number of passage attempts differed significantly between the smolts that passed through the hydropower/canal complex and those that $\operatorname{did}$ not (respectively, $\mathrm{U}$ test, $p=0.002$ and $p=0.008$ ) (Fig. 15A \& B). The median approach detection rate and passage attempts of the smolts that passed the site was 1.5 (range 1-11) and 1 (range 1-8), respectively. The median time spent in the entry zones was 04:37 (range 00:01-473:16) and differed significantly between the smolts that passed the hydropower/canal complex regardless of the migration route used

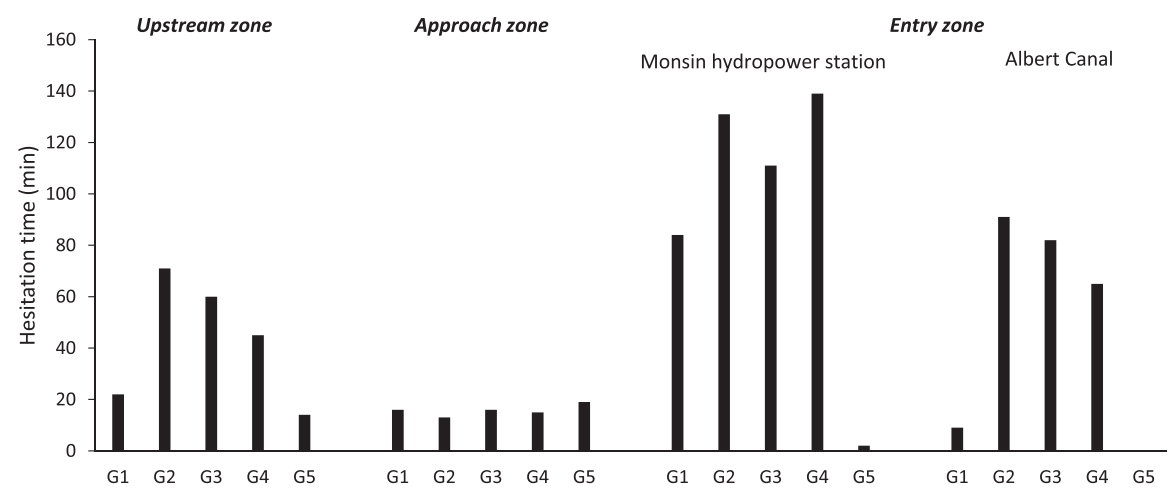

Fig. 12. Smolts' average hesitation time for each group in the different zones upstream of the hydropower/canal complex. 


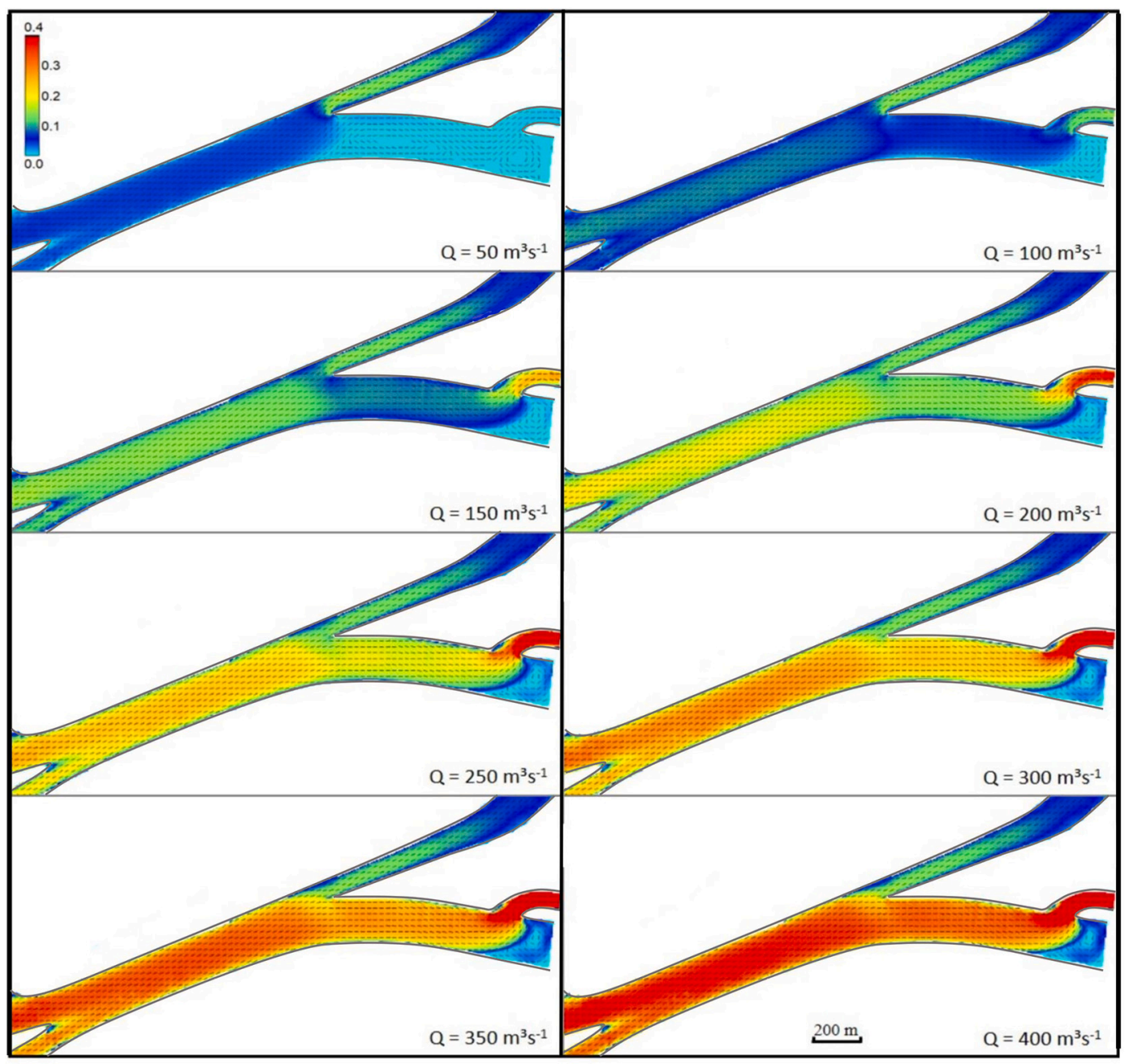

Fig. 13. Computed velocity fields between the confluence of the diversion and the main Meuse river upstream and the Albert Canal emergence and the Monsin weir/ HPP downstream for global discharge from 50 to $400 \mathrm{~m}^{3} \mathrm{~s}^{-1}$ (80\% of the discharge from the Meuse river and 20\% from the Ourthe river). Flow from left to right. In colour: velocity value in $\mathrm{ms}^{-1}$..

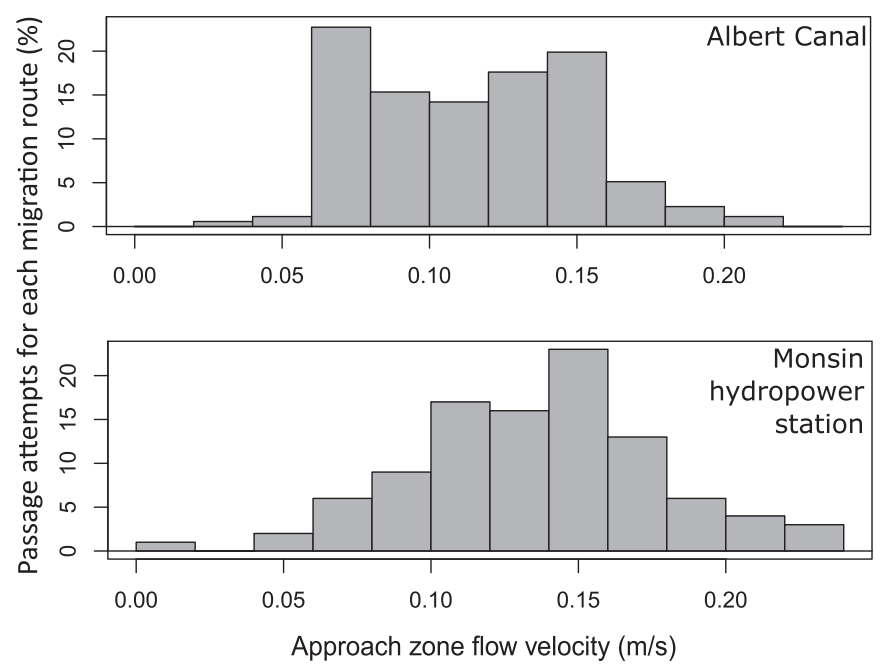

Fig. 14. All the passage attempts expressed by the smolts in the entry zones according to the approach zone flow velocity. (median $=01: 48)$ and those that did not (median $=07: 35)$ (U test, $p=$ 0.02) (Fig. 15B).

\section{Discussion}

In the present study, we coupled hydrodynamic modelling and acoustic telemetry to analyse the migratory behaviour of 72 Atlantic salmon smolts, over three consecutive years, at an experimental site that offers a bifurcation between two main migration routes: i) a hydropower station unequipped with a bypass and ii) the entrance of a navigation canal. This experimental site turned out to have a high impact and caused complex and uncommon research behaviour of the smolts, as well as definitive migration stops, associated with poor passage success. The modelling of the hydrodynamic characteristics enabled a better understanding of the influence of flow velocity and water discharge on smolts' behaviour and use of migration routes.

Over the three years of tracking, $41.5 \%$ of the migrating smolts performed back and forth movements before approaching the hydropower/canal complex for the first time. This behaviour was observed over long distances and extended over long periods, with a maximal delay of $298 \mathrm{~h}$ for one individual smolt. We observed that $13.8 \%$ of the smolts definitively stopped their migration before approaching the site. 

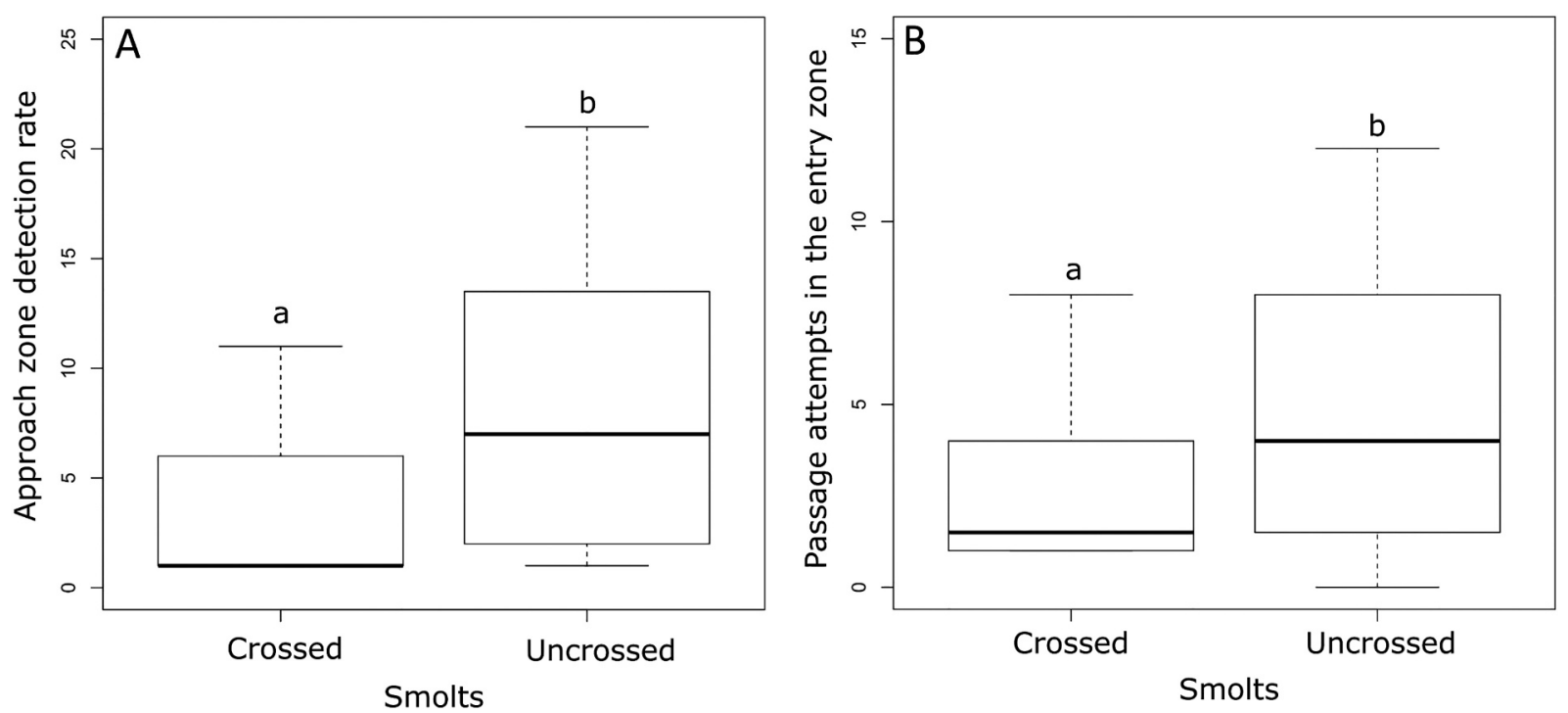

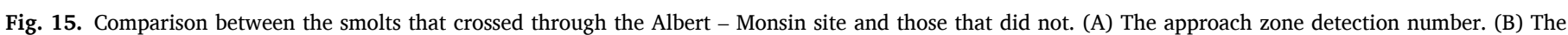

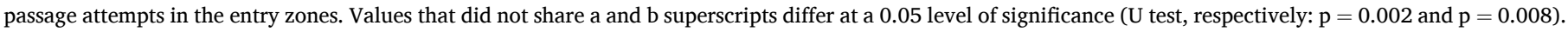

Such large-scale round-trip behaviours are uncommon and are not supposed to be observed during downstream migration, which should be unidirectional (Davidsen et al., 2005). At the confluence between the Ourthe and Meuse rivers, this behaviour could be partly explained by two anthropogenic factors. Firstly, a low water discharge and associated low flow velocity $\left(<0.15 \mathrm{~m} \mathrm{~s}^{-1}\right)$ in the Meuse river may cause disorientation of the smolts and a loss of stimulation to move downstream (Coutant and Whitney, 2000; Fjeldstad et al., 2018). Secondly, the average temperature shift of $3.3{ }^{\circ} \mathrm{C}$ between the Ourthe tributary and the Meuse river might also disturb and slow down the downstream migration stimulation by reducing gill NKA, plasma GH, and cortisol levels. This would lead to a reduction of hypo-osmoregulatory capacities and a loss of seawater tolerance, with, in the worst case, a possible desmoltification (Duston et al., 1991; McCormick et al., 1999; Bernard et al., 2019, 2020). The median migration speed of the smolts from the release site to the most downstream detection was $0.11 \mathrm{~m} \mathrm{~s}^{-1}$. The migration speeds mentioned in the literature vary between $0.09 \mathrm{~m} \mathrm{~s}^{-1}$ and $0.78 \mathrm{~m} \mathrm{~s}^{-1}$ (Stich et al., 2015; Newton et al., 2019; Renardy et al., 2020; Ovidio et al., 2021). Median migration speeds observed in un-impounded stretches ranged from $0.05 \mathrm{~m} \mathrm{~s}^{-1}$ to $0.84 \mathrm{~m} \mathrm{~s}^{-1}$ (Stich et al., 2015; Thorstad et al., 2004; Havn et al., 2018; Newton et al., 2019).

Smolt detections at the hydropower/canal complex were mainly during the dusk, night and sunrise periods. These findings are consistent with previous studies showing migration in smolts during darkness (McCormick et al., 1998; Scruton et al., 2008; Fjeldstad et al., 2012; Riley et al., 2014; Ovidio et al., 2021; Kärgenberg et al., 2020; Renardy et al., 2020). At the hydropower/canal complex, the smolts expressed different behavioural and research tactics, and most of them developed strong hesitating behaviour. The hesitation time differed greatly between the upstream and approach zones. The major hesitation times in the upstream zone were probably due to the smolts' anticipated perception of a bifurcation zone, which caused an increase of hesitating behaviour, mostly when the flow velocity was low. The hesitation time decreased with increasing flow velocity, in agreement with the observation of more frequent downstream movements. The approaching smolts were located a median of five times (range $1-474, n=57$ ) in the approach zone and performed a median of three passage attempts (range $1-36, n=56$ ) in the entry zones. The successful passage rate was $63.6 \%$ of the smolts after the two first passage attempts, whereas the $36.4 \%$ remaining smolts performed three to eight passage attempts. In smaller scale hydropower stations with multiple migration routes, Nyqvist et al.
(2017) and Renardy et al. (2020) observed the same tendency, with a majority of passages during the first and the second attempts. The smolts spent a wide range of time in the approach and entry zones before passing through the site (median research time $=04: 45$, range 00:33-473:16). In the literature, the median research time was 00:30 for Havn et al. (2020), 00:58 for Renardy et al. (2020) and varied from 00:10 to 00:54 for Tomanova et al. (2018) in small and medium-sized rivers. The longer the smolts stayed upstream of the hydropower/canal complex, the less they were able to cross the site, possibly due to energy expenditure (Svendsen et al., 2011; Nyqvist et al., 2017) and disorientation (Coutant and Whitney, 2000; Scruton et al., 2008; Brevé et al., 2014; Fjeldstad et al., 2018).

At the hydropower/canal complex, the smolts had to choose between the hydropower station and the navigation canal to pass the site. However, most of them changed their decision over time, suggesting that both migration routes are potentially repulsive and unattractive. Migrating smolts may reject a migration route due to the perception of a danger or to inadequate configuration and associated hydrodynamic conditions and therefore may look for a safer migration route (Coutant and Whitney, 2000; Enders et al., 2009; Williams et al., 2012; Kerr and Kemp, 2019), which is sometimes associated with a lower water discharge at the entrance (Havn et al., 2017). Water discharge is a significant factor for smolts during migration by facilitating the crossing of migration barriers (Nyqvist et al., 2017; Thorstad et al., 2017; Persson et al., 2019). In our study, at the first passage attempt, $54.4 \%(n=31)$ of the smolts followed the main flow, of which $n=29$ approached the Monsin hydropower station. The main flow has rarely been directed towards the Albert Canal but in such circumstances, $\mathrm{n}=2$ smolts selected this route. The choice of the migration route with the main flow is consistent with the observations of Williams et al. (2012). However, we observed that $45.6 \%$ did not follow the main flow, as was also observed in some situations by Havn et al. (2017), Kärgenberg et al. (2020) and Renardy et al. (2020). The hydrodynamic characteristics of the river such as the flow velocity also influence smolts' behaviour, as observed by Kerr and Kemp (2019) and Silva et al. (2020). In our study, hydrodynamic modelling showed that the time evolution of the Meuse discharge leads to flow velocity variations in the approach zone. Discharge lower than $250 \mathrm{~m}^{3} \mathrm{~s}^{-1}$ favoured flow velocities lower than $0.15 \mathrm{~m} \mathrm{~s}^{-1}$ and both upstream and downstream searching movements, while more oriented searching downstream movement was favoured by flow higher than $250 \mathrm{~m}^{3} \mathrm{~s}^{-1}$ and associated flow velocities higher than $0.15 \mathrm{~m} \mathrm{~s}^{-1}$. 
Among the $\mathrm{n}=57$ smolts in the approach zone, only $\mathrm{n}=22$ succeeded in passing through the hydropower/canal complex to continue migration. Among them, at the last passage attempt, $n=8$ used the Albert Canal and $n=14$ the Monsin hydropower station. The smolts that crossed the hydropower station undoubtedly used the Kaplan turbines as a migration route in 2014 and 2015 as the spillway gates of the dam were closed. In 2016, it is not excluded that some used the flow over the gates as a migration route given the higher water discharge. After their passage, three smolts were last recorded downstream of the hydropower station and probably died after the passage through the Kaplan turbines. Depending on the properties of the turbine and the operating characteristics, the mortality rate varies from $0 \%$ (Vikström et al., 2020) to $20 \%$ (Larinier and Travade, 2002). In the present study, 32\% of smolts detected in the approach zone, entered and migrated through the Albert Canal. Navigation canals may in some instances be a favourable migration route for salmonids, as suggested by Harnish et al. (2012) and Johnston et al. (2018). However, according to other studies, navigation canals turned out to be rather unfavourable notably due to fish disorientation (Hondorp et al., 2017, Acipenser fulvescens; Verhelst et al., 2018a and 2018b; Vergeynst et al., 2020, Anguilla anguilla). Of the smolts that entered the Albert Canal, 33.3\% stopped their migration at a distance of $7.7 \mathrm{~km}$ downstream from the entrance, and $44.4 \%$ returned upstream of the hydropower station. These behaviours may be explained by the completely artificial nature of the Albert Canal, with an absence of distinct and constant natural water flow and a local widening of the watercourse that may induce a reduction of stimulation to migrate downstream. The median flow velocity in the Albert Canal was $0.10 \mathrm{~m}$ $\mathrm{s}^{-1}$ and might have resulted in the round-trip behaviour of smolts. Honkanen et al. (2021) observed that, in areas of standing waters, 49\% of movements were in a direction opposite to the migration pathway. Slow-moving watercourses tend to be unattractive and prevent directional migration (Wolter and Vilcinskas, 1998; Honkanen et al., 2021). Moreover, navigation locks and boat navigation cause hydraulic disturbances with abnormal waves and currents and may further increase confusion in smolts, as observed by Wolter and Arlinghaus (2003), Verhelst et al. (2018a, 2018b), and Vergeynst et al. (2020). Migration through navigation canals also increases the risk of injuries and mortality due to potential collisions between fish and boats (Hondorp et al., 2017).

Out of the 57 smolts detected upstream of the site, $61.4 \%$ did not pass and probably died of exhaustion or predation, as stated above, after desperately searching for a migration route. The global mortality rate associated with our study site and flow conditions was therefore $66.7 \%$ ( $n=35$ non-passed \& 3 passed smolts). As a consequence, exhaustion and predation were the major cause of mortality $(55.3 \%)$ compared to passage through the turbines $(7.9 \%)$. The remaining $36.8 \%$ were last recorded upstream of the Monsin hydropower station, and may have passed the hydropower station anyway but stopped their migration before being detected by the next acoustic receiver. This means that the impact of the hydropower station in terms of mortality has to be considered holistically, by adding the different forms of mortality, including those not caused by turbines. Nyqvist et al. (2017) showed the non-passage of $35 \%$ of the smolts detected upstream of a hydropower station in a medium-sized river and the possible predation of one-third of these smolts. Keefer et al. (2013) observed mortality rates of Chinook salmon smolts between 8 and $64 \%$ due to predation at large-sized dams. Thorstad et al. (2017) and Havn et al. (2018) highlighted that living, injured or dead smolts might be predated after passing hydropower stations. However, few studies have highlighted important mortalities due to exhaustion.

For the smolts that continued their migration in the Meuse river or the Albert Canal, the escapement rate towards the Flemish region or the Netherlands part of the Meuse river was very low: $2.9 \%$ by the Albert Canal and $8.3 \%$ by the Meuse river. Vis and Spierts (2011) and Brevé et al. (2014) highlighted a seaward escapement of up to $3 \%$ of the studied Atlantic salmon smolts in the Dutch part of the Meuse river after migrating more than $230 \mathrm{~km}$ from the Roer tributary (84 km downstream of the hydropower/canal complex considered here). Despite these low seaward escapement rates, the Meuse river probably remains the best way to reach the North Sea compared to the Albert Canal, but the migration conditions have to be improved.

Several management measures may be tested and achieved to improve smolts' downstream migration at the Monsin hydropower complex and along the Meuse river to increase seaward escapement. Upstream of the Kaplan turbines, the bar screen should be combined with a downstream bypass, which would favour successful passage of migrating smolts (Larinier and Travade, 2002; Fjeldstad et al., 2018). In addition, a combination of real-time smolt monitoring and the recently developed predictive model of smolt downstream migration (Teichert et al., 2020) may be useful when mitigation measures need to be implemented, such as the opening of the spillway gates or turbines shutdown. In some instances, spillway gates may be the preferred migration route (Calles et al., 2012; Katopodis and Williams, 2012). Navigation locks in the Albert Canal might also be at a standstill at night during smolt migration to avoid a flow increase in the canal. Furthermore, an adapted management of the repartition of water flow between the Albert Canal and the Meuse river during the smolt migration period might also be tested and simulated with our hydrodynamic model before being implemented to evaluate its potential efficiency, as suggested by Szabo-Meszaros et al. (2019). Simulations would make it possible to identify if a more elevated flow to the Meuse river, opened spillway gates, or turbines shutdown would favour the passage of smolts by increasing the attractiveness of the natural watercourse and direct the smolts towards a safe migration route. To increase their efficiency, these mitigation measures should be performed as a priority during dusk and at night, which are known to be the diel migration activity times in the Meuse river basin (Ovidio et al., 2021; Renardy et al., 2020). If mitigation measures turn out to be effective after simulations, a $2 \mathrm{D}-3 \mathrm{D}$ tracking evaluation would be useful after their implementation (Silva et al., 2020).

In conclusion, the present study highlighted the negative impact of a hydropower/canal complex site on smolts' downstream migration, by offering two suboptimal, unattractive and unsafe migration routes. The site caused disorientation and energy expenditure, which resulted in significant delays and mortality, and considerably affected the subsequent seaward escapement. The re-establishment of sustainable Atlantic salmon (and sea trout, Salmo trutta Linnaeus, 1758) populations in the international Meuse river basin is a challenging project that started at the beginning of the 1990s (Philippart et al., 1994). From 2000 to 2020, the number of returning Atlantic salmon and sea trout progressively increased, but not enough to achieve a self-sustainable population. The ecological state of the Meuse river basin was greatly improved in terms of the physical and chemical quality of the water and the construction of a fishway for upstream movements of adults, but the downstream migration of the smolts and the associated escapement success remains one of the main problems for the success of the reintroduction project.

\section{Credit author statement}

Séverine RENARDY:Formal analysis, data treatment, writing original draft, writing review and editing, validation, visualization. Abderrahmane TAKRIET: Formal analysis, data analysis and modelling. Jean-Philippe BENITEZ: Conceptualization, methodology, field work, formal analysis, paper proofreading. Arnaud DIERCKX: Conceptualization, methodology, field work, data monitoring. Raf BAEYENS: Conceptualization, methodology, field work, data monitoring, paper proofreading. Johan COECK: Supervision, project administration, funding acquisition, paper proofreading. Ine S. PAUWELS: field work, paper proofreading. Ans MOUTON: Conceptualization, methodology, field work, data monitoring, paper proofreading. Pierre ARCHAMBEAU: Development of the modelling software. Benjamin DEWALS: Development of the modelling software, paper 
proofreading. Michel PIROTTON: Development of the modelling software. Sébastien ERPICUM: Development of the modelling software, data analysis and modelling, writing review and editing, paper proofreading. Michaël OVIDIO: Conceptualization, methodology, co-writing original draft, co-writing review and editing, supervision, project administration, funding acquisition.

\section{Declaration of Competing Interest}

The authors declare that they have no known competing financial interests or personal relationships that could have appeared to influence the work reported in this paper.

\section{Acknowledgments}

The Authors acknowledge the Service Public de Wallonie for providing bathymetry data and discharge/water level data at the different gauging stations. They also acknowledge Luminus Company for providing discharge data at Ivoz Ramet and Monsin HPP. Séverine Renardy received a Ph.D. research grant from FRIA ('Fonds pour la Formation à la Recherche dans l'Industrie et dans l'Agriculture') for a project on the smolt downstream migration. HECE work was partly funded by the LIFE program LIFE4FISH (LIFE16/NAT/BE/000807)

\section{References}

Baras, E., Lucas, M.C., 2001. Impacts of man's modifications of river hydrology on the migration of freshwater fishes: a mechanistic perspective. Int. J. Ecohydrol. \& Hydrobiol. 1 (3), 291-304.

Benitez, J.P., Dierckx, A., Matondo, B.N., Rollin, X., Ovidio, M., 2018. Movement behaviours of potamodromous fish within a large anthropised river after the reestablishment of the longitudinal connectivity. Fish. Res. 207, 140-149.

Bernard, B., Mandiki, S.N., Duchatel, V., Rollin, X., Kestemont, P., 2019. A temperature shift on the migratory route similarly impairs hypo-osmoregulatory capacities in two strains of Atlantic salmon (Salmo salar L.) smolts. Fish Physiol. Biochem. 45 (4), 1245-1260.

Bernard, B., Leguen, I., Mandiki, S.N., Cornet, V., Redivo, B., Kestemont, P., 2020. Impact of temperature shift on gill physiology during smoltification of Atlantic salmon smolts (Salmo salar L.). Comp. Biochem. Physiol. 244, 1-10.

Brevé, N., Vis, H., Spierts, I., de Laak, G., Moquette, F., Breukelaar, A., 2014. Exorbitant mortality of hatchery-reared Atlantic salmon smolts Salmo salar L., in the Meuse river system in the Netherlands. J. Coast. Conserv. 18 (2), 97-109.

Calles, O., Karlsson, S., Hebrand, M., Comoglio, C., 2012. Evaluating technical improvements for downstream migrating diadromous fish at a hydroelectric plant. Ecol. Eng. 48, 30-37.

Castro-Santos, T., Perry, R., 2012. Time-to-event analysis as a framework for quantifying fish passage performance. In: Adams, N.S., Beeman, J.W., Eiler, J.H. (Eds.), Telemetry Techniques: A User Guide for Fisheries Research. American Fisheries Society, Bethesda, Maryland, pp. 427-452.

Cheng, Y.W., Gallinat, M.P., 2004. Statistical analysis of the relationship among environmental variables, inter-annual variability and smolt trap efficiency of salmonids in the Tucannon River. Fish. Res. 70 (2-3), 229-238.

Coutant, C.C., Whitney, R.R., 2000. Fish behavior in relation to passage through hydropower turbines: a review. Trans. Am. Fish. Soc. 129 (2), 351-380.

Davidsen, J., Svenning, M.A., Orell, P., Yoccoz, N., Dempson, J.B., Niemelä, E., Erkinaro, J., 2005. Spatial and temporal migration of wild Atlantic salmon smolts determined from a video camera array in the sub-Arctic River Tana. Fish. Res. 74 (1-3), 210-222.

Duston, J., Saunders, R.L., Knox, D.E., 1991. Effects of increases in freshwater temperature on loss of smolt characteristics in Atlantic salmon (Salmo salar). Can. J. Fish. Aquat. Sci. 48, 164-169.

Enders, E.C., Gessel, M.H., Williams, J.G., 2009. Development of successful fish passage structures for downstream migrants requires knowledge of their behavioural response to accelerating flow. Can. J. Fish. Aquat. Sci. 66 (12), 2109-2117.

Erpicum, S., Meile, T., Dewals, B., Pirotton, M., Schleiss, A., 2009. 2D numerical flow modellingin a macro-rough channel. Int. J. Numer. Methods Fluids 61 (11), 1227-1246.

Erpicum, S., Dewals, B., Archambeau, P., Pirotton, M., 2010a. Dam-break flow computation based on an efficient flux-vector splitting. J. Comput. Appl. Math. 2143-2151.

Erpicum, S., Dewals, B., Archambeau, P., Detrembleur, S., Pirotton, M., 2010b. Detailed inundation modelling using high resolution DEMs. Eng Appl Comput Fluid Mech 2 (4), 196-208.

Fjeldstad, H.P., Uglem, I., Diserud, O.H., Fiske, P., Forseth, T., Kvingedal, E., Järnegren, J., 2012. A concept for improving Atlantic salmon Salmo salar smolt migration past hydro power intakes. J. Fish Biol. 81 (2), 642-663.
Fjeldstad, H.P., Pulg, U., Forseth, T., 2018. Safe two-way migration for salmonids and eel past hydropower structures in Europe: a review and recommendations for bestpractice solutions. Mar. Freshw. Res. 69 (12), 1834-1847.

Fu, T., Deng, Z.D., Duncan, J.P., Zhou, D., Carlson, T.J., Johnson, G.E., Hou, H., 2016. Assessing hydraulic conditions through Francis turbines using an autonomous sensor device. Renew. Energy 99, 1244-1252.

Haraldstad, T., Höglund, E., Kroglund, F., Haugen, T.O., Forseth, T., 2018. Common mechanisms for guidance efficiency of descending Atlantic salmon smolts in small and large hydropower power plants. River Res. Appl. 34 (9), 1179-1185.

Haraldstad, T., Haugen, T.O., Kroglund, F., Olsen, E.M., Höglund, E., 2019. Migratory passage structures at hydropower plants as potential physiological and behavioural selective agents. R. Soc. Open Sci. 6 (11), 190989.

Harnish, R.A., Johnson, G.E., McMichael, G.A., Hughes, M.S., Ebberts, B.D., 2012. Effect of migration pathway on travel time and survival of acoustic-tagged juvenile salmonids in the Columbia River estuary. Trans. Am. Fish. Soc. 141 (2), 507-519.

Havn, T.B., Sæther, S.A., Thorstad, E.B., Teichert, M.A.K., Heermann, L., Diserud, O.H., Økland, F., 2017. Downstream migration of Atlantic salmon smolts past a low head hydropower station equippped with Archimedes screw and Francis turbines. Ecol. Eng. 105, 262-275.

Havn, T.B., Thorstad, E.B., Teichert, M.A., Sæther, S.A., Heermann, L., Hedger, R.D., Økland, F., 2018. Hydropower-related mortality and behaviour of Atlantic salmon smolts in the River Sieg, a German tributary to the Rhine. Hydrobiologia 805 (1), 273-290.

Havn, T.B., Thorstad, E.B., Borcherding, J., Heermann, L., Teichert, M.A., Ingendahl, D., $\varnothing$ kland, F., 2020. Impacts of a weir and power station on downstream migrating Atlantic salmon smolts in a German river. River Res. Appl. 36 (5), 784-796.

Holbrook, C.M., Kinnison, M.T., Zydlewski, J., 2011. Survival of migrating Atlantic salmon smolts through the Penobscot River, Maine: a prerestoration assessment. Trans. Am. Fish. Soc. 140 (5), 1255-1268.

Hondorp, D.W., Bennion, D.H., Roseman, E.F., Holbrook, C.M., Boase, J.C., Chiotti, J.A., Krueger, C.C., 2017. Use of navigation channels by Lake Sturgeon: does channelization increase vulnerability of fish to ship strikes? PLoS One 12 (7).

Honkanen, H.M., Orrell, D.L., Newton, M., McKelvey, S., Stephen, A., Duguid, R.A., Adam, C.E, 2021. The downstream migration success of Atlantic salmon (Salmo salar) smolts through natural and impounded standing waters. Ecol. Eng. 161, 1-10.

Huet, M., 1949. Aperçu des relations entre la pente et les populations piscicoles des eaux courantes. Schweiz. Z. Hydrol. 11 (3-4), 332-351.

Johnston, M.E., Steel, A.E., Espe, M., Sommer, T., Klimley, A.P., Sandstrom, P., Smith, D., 2018. Survival of juvenile Chinook salmon in the Yolo Bypass and the lower Sacramento River, California. San Franc. Estuary Watershed Sci. 16 (2).

Kärgenberg, E., Thorstad, E.B., Järvekülg, R., Sandlund, O.T., Saadre, E., Økland, F., Tambets, M., 2020. Behaviour and mortality of downstream migrating Atlantic salmon smolts at a small power station with multiple migration routes. Fish. Manag. Ecol. 27 (1), 32-40.

Katopodis, C., Williams, J.G., 2012. The development of fish passage research in a historical context. Ecol. Eng. 48, 8-18.

Keefer, M.L., Taylor, G.A., Garletts, D.F., Helms, C.K., Gauthier, G.A., Pierce, T.M., Caudill, C.C., 2013. High-head dams affect downstream fish passage timing and survival in the Middle Fork Willamette River. River Res. Appl. 29 (4), 483-492.

Kerr, J.R., Kemp, P.S., 2019. Masking a fish's detection of environmental stimuli: application to improving downstream migration at river infrastructure. J. Fish Biol. 95 (1), 228-237.

Koed, A., Jepsen, N., Aarestrup, K., Nielsen, C., 2002. Initial mortality of radio-tagged Atlantic salmon (Salmo salar L.) smolts following release downstream of a hydropower station. In: Aquatic Telemetry (pp. 31-37). Springer, Dordrecht.

Larinier, M., Travade, F., 2002. Downstream migration: problems and facilities. Bull. Fr. Peche Piscic. 181-207.

Lin, H.Y., Cooke, S.J., Wolter, C., Young, N., Bennett, J.R., 2020. On the conservation value of historic canals for aquatic ecosystems. Biol. Conserv. 251, 108764.

Marschall, E.A., Mather, M.E., Parrish, D.L., Allison, G.W., McMenemy, J.R., 2011. Migration delays caused by anthropogenic barriers: modelling dams, temperature, and success of migrating salmon smolts. Ecol. Appl. 21 (8), 3014-3031.

McCormick, S.D., Hansen, L.P., Quinn, T.P., Saunders, R.L., 1998. Movement, migration, and smolting of Atlantic salmon (Salmo salar). Can. J. Fish. Aquat. Sci. 55 (S1), 77-92.

McCormick, S.D., Cunjak, R.A., Dempson, B., O’Dea, M.F., Carey, J.B., 1999. Temperature-related loss of smolt characteristics in Atlantic salmon (Salmo salar) in the wild. Can. J. Fish. Aquat. Sci. 56 (9), 1649-1667.

Newton, M., Barry, J., Dodd, J.A., Lucas, M.C., Boylan, P., Adams, C.E., 2019. A test of the cumulative effect of river weirs on downstream migration success, speed and mortality of Atlantic salmon (Salmo salar) smolts: an empirical study. Ecol. Freshw. Fish 28 (1), 176-186.

Nilsson, C., Reidy, C.A., Dynesius, M., Revenga, C., 2005. Fragmentation and flow regulation of the world's large river systems. Science 308 (5720), 405-408.

Noatch, M.R., Suski, C.D., 2012. Non-physical barriers to deter fish movements. Environ. Rev. 20 (1), 71-82.

Nyqvist, D., Greenberg, L.A., Goerig, E., Calles, O., Bergman, E., Ardren, W.R., CastroSantos, T., 2017. Migratory delay leads to reduced passage success of Atlantic salmon smolts at a hydropower dam. Ecol. Freshw. Fish 26 (4), 707-718.

Ovidio, M., Dierckx, A., Bunel, S., Grandry, L., Spronck, C., Benitez, J.P., 2017. Poor performance of a retrofitted downstream bypass revealed by the analysis of approaching behaviour in combination with a trapping system. River Res. Appl. 33 (1), 27-36.

Ovidio, M., Renardy, S., Dierckx, A., Matondo, B.N., Benitez, J.P., 2021. Improving bypass performance and passage success of Atlantic salmon smolts at an old fishhostile hydroelectric power station: a challenging task. Ecolog. Eng. 160, 1-11. 
Ovidio, M., Sonny, D., Watthez, Q., Goffaux, D., Detrait, O., Orban, P., Matondo, B.N., Renardy, S., Dierckx, A., Benitez, J.P., 2020. Evaluation of the performance of successive multispecies improved fishways to reconnect a rehabilitated river. Wetlands Ecol. Manag. 28 (4), 641-654.

Parrish, D.L., Behnke, R.J., Gephard, S.R., McCormick, S.D., Reeves, G.H., 1998. Why aren't there more Atlantic salmon (Salmo salar)? Can. J. Fish. Aquat. Sci. 55 (1), $281-287$.

Pauwels, I.S., Baeyens, R., Toming, G., Schneider, M., Buysse, D., Coeck, J., Tuhtan, J.A., 2020. Multi-Species Assessment of Injury, Mortality, and Physical Conditions during Downstream Passage through a large Archimedes Hydrodynamic Screw (Albert Canal, Belgium). Sustainability 12 (20), 8722.

Persson, L., Kagervall, A., Leonardsson, K., Royan, M., Alanärä, A., 2019. The effect of physiological and environmental conditions on smolt migration in Atlantic salmon Salmo salar. Ecol. Freshw. Fish 28 (2), 190-199.

Philippart, J.C., Micha, J.C., Baras, E., Prignon, C., Gillet, A., Joris, S., 1994. The Belgian project "meuse salmon 2000". First results, problems and future prospects. Water Sci. Technol. 29 (3), 315-317.

Renardy, S., Benitez, J.P., Tauzin, A., Dierckx, A., Matondo, B.N., Ovidio, M., 2020. How and where to pass? Atlantic salmon smolt's behaviour at a hydropower station offering multiple migration routes. Hydrobiologia 847 (2), 469-485.

Riley, W.D., Ibbotson, A.T., Maxwell, D.L., Davison, P.I., Beaumont, W.R.C., Ives, M.J., 2014. Development of schooling behaviour during the downstream migration of Atlantic salmon Salmo salar smolts in a chalk stream. J. Fish Biol. 85 (4), 1042-1059.

Scruton, D.A., Pennell, C.J., Bourgeois, C.E., Goosney, R.F., King, L., Booth, R.K., Clarke, K.D., 2008. Hydropowerity and fish: a synopsis of comprehensive studies of upstream and downstream passage of anadromous wild Atlantic salmon, Salmo salar, on the Exploits River, Canada. Hydrobiologia 609 (1), 225-239.

Serrano, I., Rivinoja, P., Karlsson, L., Larsson, S., 2009. Riverine and early marine survival of stocked salmon smolts, Salmo salar L., descending the Testebo River, Sweden. Fish. Manage. Ecol. 16 (5), 386-394.

Silva, A.T., Lucas, M.C., Castro-Santos, T., Katopodis, C., Baumgartner, L.J., Thiem, J.D., Burnett, N.J., 2018. The future of fish passage science, engineering, and practice. Fish Fish (Oxf) 19 (2), 340-362.

Silva, A.T., Bærum, K.M., Hedger, R.D., Baktoft, H., Fjeldstad, H.P., Gjelland, K.Ø., Forseth, T., 2020. The effects of hydrodynamics on the three-dimensional downstream migratory movement of Atlantic salmon. Sci. Total Environ. 705, 135773.

Steel, A.E., Sandstrom, P.T., Brandes, P.L., Klimley, A.P., 2013. Migration route selection of juvenile Chinook salmon at the Delta Cross Channel, and the role of flow velocity and individual movement patterns. Environ. Biol. Fish 96 (2-3), 215-224.

Stich, D.S., Zydlewski, G.B., Kocik, J.F., Zydlewski, J.D., 2015. Linking behavior, physiology, and survival of Atlantic salmon smolts during estuary migration. Mar Coast Fish 7 (1), 68-86.

Svendsen, J.C., Aarestrup, K., Malte, H., Thygesen, U.H., Baktoft, H., Koed, A., McKinley, R.S., 2011. Linking individual behaviour and migration success in Salmo salar smolts approaching a water withdrawal site: implications for management. Aquat. Living Resour. 24 (2), 201-209.

Szabo-Meszaros, M., Forseth, T., Baktoft, H., Fjeldstad, H.P., Silva, A.T., Gjelland, K.Ø., Alfredsen, K., 2019. Modelling mitigation measures for smolt migration at dammed river sections. Ecohydrology 12 (7), e2131.

Teichert, N., Benitez, J.P., Dierckx, A., Tétard, S., de Oliveira, E., Trancart, T., Ovidio, M. 2020. Development of an accurate model to predict the phenology of Atlantic salmon smolt spring migration. Aquat. Conserv. Mar. Freshwat. Ecosyst. 30 (8), 1552-1565.
Tetard, S., Maire, A., Lemaire, M., De Oliveira, E., Martin, P., Courret, D., 2019. Behaviour of Atlantic salmon smolts approaching a bypass under light and dark conditions: Importance of fish development. Ecol. Eng. 131, 39-52.

Thorstad, E., Finstad, B., Sivertsgrd, R., Bjorn, P., McKinleyd, R., 2004. Migration speeds and orientation of Atlantic salmon and sea trout post-smolts in a Norwegian fjord system. Environ. Biol. Fish 71 (3), 305-311.

Thorstad, E.B., Økland, F., Aarestrup, K., Heggberget, T.G., 2008. Factors affecting the within-river spawning migration of Atlantic salmon, with emphasis on human impacts. Rev. Fish Biol. Fish. 18 (4), 345-371.

Thorstad, E.B., Whoriskey, F., Uglem, I., Moore, A., Rikardsen, A.H., Finstad, B., 2012. A critical life stage of the Atlantic salmon Salmo salar: Behaviour and survival during the smolt and initial post-smolt migration. J. Fish Biol. 81 (2), 500-542.

Thorstad, E.B., Havn, T.B., Sæther, S.A., Heermann, L., Teichert, M.A.K., Diserud, O.H., $\varnothing \mathrm{kland}, \mathrm{F} ., 2017$. Survival and behaviour of Atlantic salmon smolts passing a run-ofriver hydropower facility with a movable bulb turbine. Fish. Manag. Ecol. 24 (3), 199-207.

Tomanova, S., Courret, D., Alric, A., De Oliveira, E., Lagarrigue, T., Tétard, S., 2018. Protecting efficiently sea-migrating salmon smolts from entering hydropower plant turbines with inclined or oriented low bar spacing racks. Ecol. Eng. 122, 143-152.

Vergeynst, J. (2018). Fish behaviour in the vicinity of a navigation lock complex: the challenges, Daniel Bung, Blake Tullis, 7th IAHR International Symposium on Hydraulic Structures, Aachen, Germany, 15-18 May. Doi: 10.15142/T3S35D(978-0692-13277-7).

Vergeynst, J., Pauwels, I., Baeyens, R., Coeck, J., Nopens, I., De Mulder, T., Mouton, A., 2019. The impact of intermediate-head navigation locks on downstream fish passage. River Res. Appl. 35 (3), 224-235.

Vergeynst, J., Pauwels, I., Baeyens, R., Mouton, A., De Mulder, T., Nopens, I., 2020. Shipping canals on the downstream migration route of European eel: opportunity or bottleneck? Ecol. Freshw. Fish 30 (1), 73-87.

Verhelst, P., Baeyens, R., Reubens, J., Benitez, J.P., Coeck, J., Goethals, P., Mouton, A., 2018a. European silver eel (Anguilla anguilla L.) migration behaviour in a highly regulated shipping canal. Fish. Res. 206, 176-184.

Verhelst, P., Buysse, D., Reubens, J., Pauwels, I., Aelterman, B., Van Hoey, S., Mouton, A., 2018b. Downstream migration of European eel (Anguilla anguilla L.) in an anthropogenically regulated freshwater system: Implications for management. Fish. Res. 199, 252-262.

Vikström, L., Leonardsson, K., Leander, J., Shry, S., Calles, O., Hellström, G., 2020. Validation of Francis-Kaplan turbine blade strike models for adult and Juvenile Atlantic Salmon (Salmo Salar, L.) and Anadromous Brown Trout (Salmo Trutta, L.) passing high head turbines. Sustainability 12 (16), 1-13.

Vis, H., Spierts, I.L.Y., 2011. Research on downstream migration of salmon smolts (tagging/tracking), from tributary Roer into the river Meuse and the North Sea. VisAd-vies BV, Nieuwegein. Project number VA2011_01, 33 pag.

Williams, J.G., Armstrong, G., Katopodis, C., Larinier, M., Travade, F., 2012. Thinking like a fish: a key ingredient for development of effective fish passage facilities at river obstructions. River Res. Appl. 28 (4), 407-417.

Wolter, C., Arlinghaus, R., 2003. Navigation impacts on freshwater fish assemblages: the ecological relevance of swimming performance. Rev. Fish Biol. Fish. 13 (1), 63-89.

Wolter, C., Vilcinskas, A., 1998. Effects of canalization on fish migrations in canals and regulated rivers. Arch Polish Fish 45 (1), 91-101. 